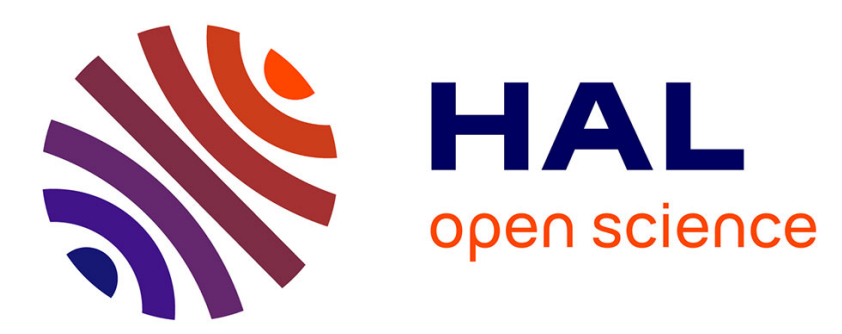

\title{
Business Model Research: A Bibliometric Analysis of Origins and Trends
}

Raphaël Maucuer, Alexandre Renaud

\section{To cite this version:}

Raphaël Maucuer, Alexandre Renaud. Business Model Research: A Bibliometric Analysis of Origins and Trends. M@n@gement, In press. hal-01918188

\section{HAL Id: hal-01918188 \\ https://hal.science/hal-01918188}

Submitted on 21 Nov 2018

HAL is a multi-disciplinary open access archive for the deposit and dissemination of scientific research documents, whether they are published or not. The documents may come from teaching and research institutions in France or abroad, or from public or private research centers.
L'archive ouverte pluridisciplinaire HAL, est destinée au dépôt et à la diffusion de documents scientifiques de niveau recherche, publiés ou non, émanant des établissements d'enseignement et de recherche français ou étrangers, des laboratoires publics ou privés. 


\title{
ARTICLE IN PRESS
}

\section{Business Model Research:}

\section{A Bibliometric Analysis of Origins and Trends}

\author{
Raphaël Maucuer - ESSCA School of Management \\ raphael.maucuer@essca.fr
}

\author{
Alexandre Renaud - EM Normandie \\ arenaud@em-normandie.fr
}

\section{FORTHCOMING IN M@N@GEMENT}

\begin{abstract}
:
The business model (BM) concept has become a major area of interest in Management literature, leading to the publication of a host of literature reviews and essays aimed at synthesizing and interpreting the development of BM research. Yet these general analyses have largely neglected the specificities of the two main disciplines in which the BM concept is anchored: Strategic Management and Innovation \& Entrepreneurship. Accordingly, this article seeks to explore the intellectual roots and current trends of these disciplines to refine our understanding of the development of the BM literature.

We draw on a mixed bibliometric analysis based on two samples of respectively 208 and 345 articles published in Strategic Management and Innovation \& Entrepreneurship. This analysis enables us to compare the theoretical pillars (co-citation analysis) and research fronts (bibliographic coupling analysis) of BM research in these two foundational disciplines.

Our results suggest a certain homogeneity within both the theoretical pillars of the disciplines and the incremental diversification of their research fronts. In light of these findings, we consider the future of the BM literature and accordingly propose a twofold developmental strategy for it.
\end{abstract}

Keywords: Business Model; Research Field; Bibliometrics; Co-Citation Analysis; Bibliographic Coupling Analysis. 


\section{ARTICLE IN PRESS}

\section{Business Model Research:}

\section{A Bibliometric Analysis of Origins and Trends}

\section{INTRODUCTION}

Since the 2000s, the business model (BM) concept has become increasingly popular in Management literature (Zott, Amit \& Massa, 2011), particularly in disciplines such as Strategic Management (Baden-Fuller, Demil, Lecocq \& MacMillan, 2010), Innovation (Schneider \& Spieth, 2013), Entrepreneurship (Demil, Lecocq, Ricart \& Zott, 2015), and—albeit to a lesser extentInformation Systems Management (Al-Debei \& Avison, 2010). The BM is seen as a powerful concept (Shafer, Smith \& Linder, 2005) with strong explanatory power (Baden-Fuller \& Morgan, 2010) that enables crosscutting examination of performance drivers in both well-established (Demil \& Lecocq, 2010) and emerging firms (Doganova \& Eyquem-Renault, 2009). Together, these developments have led to the emergence of a new research field—which Lecocq, Demil and Ventura (2010) view as a progressive research program (in the vein of Lakatos, 1969 \& 1970) whose development has been buttressed by the creation of research platforms such as the Business Model Community, the Journal of Business Models, or the more recent Business Model Conference.

Despite this evolution, the BM literature has struggled to settle on a unified view which has led to a troubling and ongoing conceptual heterogeneity (Wirtz, Pistoia, Ullrich \& Göttel, 2016; Massa, Tucci \& Afuah, 2017). Various explanations have been put forward to account for this heterogeneity, including the concept's lack of theoretical underpinnings (Porter, 2001), its novelty (Osterwalder, Pigneur \& Tucci, 2005), the broadness of its definitions (Zott \& Amit, 2013), and 


\section{ARTICLE IN PRESS}

the language games employed in related research (Klang, Wallnöfer \& Hacklin, 2014). Among these explanations, one has gone through the years: the heterogeneity of BM definitions lies in the fact that the concept has been developed in silos (Massa, et al., 2017; Wirtz, et al., 2016; Zott, et al., 2011). This assertion suggests that the numerous and diverse BM approaches have developed in isolation in distinct disciplinary fields, in line with authors' respective research interests.

Not only has this heterogeneity been an ongoing source of confusion for BM research (Massa, et al., 2017; Zott \& Amit, 2013), it has also undermined the concept's value and hindered the development of the related-literature (Klang, et al., 2014). Indeed, authors have made repeated attempts at proposing definitive definitions of the concept, which have largely consisted of developing "new" definitions based on wording comparable to previous ones. This results in systematically devaluating former definitions, and thus weakens the legitimacy of the concept more generally. Similarly, this headlong conceptual rush prevents the development of more cumulative works and innovative perspectives rooted in a single benchmark conceptualization. In sum, this lack of clarity represents a major obstacle in moving BM from being a simple concept to being a unified field of research, and inadvertently calls the rigor and relevance of BM research into question.

Moreover, the esoteric debates over the definitions have limited the literature's ability to offer up more practical contributions and to provide guidelines for managers. Such practical concerns should be systematically addressed, especially given the concept's business origins (Lecocq, et al., 2010). This deficiency has not gone unnoticed, however, and researchers have begun calling for work on BM to provide relevant insights for practitioners (Mangematin, Ravarini \& Sharkey Scott, 2017). The conceptual weaknesses have also generated a series of misunderstandings in the business sphere: over the past two decades, this term has frequently been misinterpreted and 


\section{ARTICLE IN PRESS}

misused by managers, consultants, scholars, and even by media outlets (DaSilva \& Trkman, 2014). Such confusions may have detrimental effects on decisions makers' business analyses.

Over the years, a considerable amount of research has been aimed at conclusively developing a commonly accepted definition of BM (Appendix A); for instance, scholars have focused on the core hypotheses of the concept (Lecocq, et al., 2010), the themes that converge on it (Zott, et al., 2011), integrative definitions (Wirtz, et al., 2016), or even “consensual” definitions (Moingeon \& Lehmann-Ortega, 2010). However, the heterogeneity remains a defining feature of the literature since recent studies — all based on systematic literature review (Webster \& Watson, 2002) —offer different conclusions.

Wirtz et al. (2016), for example, provide an exhaustive review of the BM corpus, concluding that "there is still quite a heterogeneous, albeit recently converging, understanding of the term business model in theory and practice" (p. 50). These authors hold that the different conceptualizations of BM tend to converge, and accordingly propose an umpteenth "integrative" definition. Conversely, Massa et al. (2017) point towards the emergence of "three interpretations of the meaning" (p. 73) of the concept. For their part, Foss and Saebi (2017) consider the concept's heterogeneity is superficial and largely the fault of other authors' formulations: "Although definitions differ across studies [...], most current definitions are close to or consistent with Teece's (2010: 172) definition of a $B M^{\prime \prime}$ (p. 3). In the face of these conflicting interpretations, we hold that the issue of heterogeneity remains unsolved.

Given these challenges, this article aims at exploring the issue of heterogeneity from a renewed perspective. From this perspective, we can cite three limitations common to literature reviews of BM-related work. Firstly, these reviews systematically rely on a transdisciplinary approach. Although research studies see the heterogeneity as a consequence of disciplinary specificity 


\section{ARTICLE IN PRESS}

(Massa, et al., 2017; Wirtz, et al., 2016; Zott, et al., 2011), the literature reviews' methodologies fail to take these specificities into account. They analyze the literature as a whole in an effort to provide generic interpretations of its research output. In our view, this approach is ill-equipped to provide a nuanced understanding of the heterogeneity. Instead, we believe that disciplinary specificities must be compared as a means of capturing their relative influence and specificities in the conceptualizations of BM.

Secondly, these subjective literature reviews (Webster \& Watson, 2002) draw on textual analyses of definitions (i.e. researchers' explicit formulations), yet ignore the implicit theoretical origins of BM research, namely the scientific knowledge on which it has been and is being built. For this reason, we hold that focusing on the terminology of such definitions cannot provide a reliable analysis of BM's "lack of a uniform theoretical foundation" (Wirtz, et al., 2016, p. 37). Instead, we believe it can only be overcome by exploring and comparing the theoretical pillars of the main disciplines currently investigating BMs.

Finally, the authors of these literature reviews focus mainly on conceptual heterogeneity in identifying the different perspectives and definitions of the concept; however, we hold that contentrelated specificities (i.e. areas of research) of the relevant disciplines should also be examined to provide a full-fledged analysis. In other words, both the origins and the current trends of BM research must be taken into consideration.

In this article, we aim to overcome these methodological limitations by addressing the following research issue: What are the disciplinary specificities of the BM concept? In answering this question, we will address and detail two distinct yet related types of heterogeneity to determine the extent to which certain "silos" (Zott, et al., 2011) — the disciplines involved in the BM literature- 


\section{ARTICLE IN PRESS}

have had an impact on the meaning of the concept and on related research content. Thus, we will consider two central sub-questions as we consider research dealing with the concept of BM:

- What are the disciplinary specificities of the BM concept in terms of its theoretical foundations? (RQ1)

- What are the disciplinary specificities of the BM concept in terms of its current research areas? (RQ2)

To answer these questions, we have drawn on bibliometric methods (De Solla Price, 1963). These methods - which are largely based in statistics - provide greater objectivity and accuracy than traditional literature reviews (Tranfield, Denyer \& Smart, 2003) in terms of their treatment and ability to analyze a large set of scientific publications. Armed with these methods, we carried out two comparative analyses of the BM literature published in the two main disciplines that deal with the concept: Strategic Management (208 articles) and Innovation \& Entrepreneurship (345 articles).

In doing so, we first highlighted the intellectual structures of these disciplines (RQ1) (i.e. the scientific literatures on which each discipline has built its perspectives on BMs) through a comparative co-citation analysis (CCA) (Garfield, 1979; Small, 1973). This analysis helped us to uncover the research field's developmental history and to thus identify its intellectual roots. We then focused on the actual issues that researchers in both disciplines had investigated (RQ2) by conducting a bibliographic coupling analysis (BCA) (Kessler, 1960). This analysis allowed us to highlight the diversity of researchers' interests as well as the discrepancies in the respective dynamics of each discipline. 


\section{ARTICLE IN PRESS}

Our results provide compelling answers to the two research questions above. The CCA results demonstrate that both of these literatures draw upon equivalent intellectual cores, themselves clustered into similar and consistent invisible colleges. Contrary to what is generally suggested in the literature on BM, these results show that the different disciplines—or "silos"-have remarkably similar theoretical backgrounds. Thus, the heterogeneity of the BM concept cannot be attributed to such silos (Zott, et al., 2011), a fact that to a certain extent discredits the idea of a "convergence process" in the context of the concept's development (Wirtz, et al., 2016).

Despite their common intellectual bases, however, the results of our BCA show that the two disciplines have developed their own specific areas of research and have followed two different paths of development. In this regard, our results suggest the existence a substantial heterogeneity within the status of the concept between these two disciplines: while the Strategic Management literature views $\mathrm{BM}$ as a central research object (itself anchored in two ontologies), the Innovation \& Entrepreneurship literature has tended to develop its important streams of research by considering the concept as a tool.

The contribution of this study is threefold. Firstly, thanks to our "disciplinary" approach based in bibliometric techniques, our results lend further nuance to the general understanding of BM research dynamics, and in turn, enable us to provide a meaningful historical perspective by investigating the origins of these dynamics. Secondly, in regard to the dynamics of future BM research, we suggest two strategies for the development of the literature: the cross-fertilization of its component disciplines, and the diversification of the literature into specific themes. The third contribution is methodological. We conduct an original study of the BM literature based on a combination of two bibliometric methods (CCA and $\mathrm{BCA}$ ) that allowed us to obtain a nuanced understanding of the hidden dynamics of the scientific literature on BMs. 


\section{ARTICLE IN PRESS}

This article is organized as follows. After first describing our methodology, we detail the results of our two studies. We then discuss our results before finally considering the contributions and limitations, as well as a number of potential avenues for future research.

\section{MIXED BIBLIOMETRIC METHODS}

Scientific works are said to cluster into informal networks within which similar issues are addressed in comparable ways (De Solla Price, 1963). This phenomenon can be in turn analyzed through a concentration on the references cited by authors (which reveal theoretical pillars and epistemological perspectives) or by investigating a particular literature's content (which sheds light on current topics of interest). Similarly, for this study we have conducted a comparative bibliometric analysis of the two main disciplines in the BM literature: Strategic Management and Innovation \& Entrepreneurship.

\section{PRINCIPLES OF BIBLIOMETRIC METHODS}

In general, three main methods are used to analyze a specific scientific corpus. In the first of thesethe traditional literature review-, researchers use relevant criteria to interpret the literature (Webster \& Watson, 2002). This approach relies on researchers' subjectivity and often suffers from a lack of rigor (Tranfield, Denyer \& Smart, 2003). The second method - the quantitative metaanalysis of the literature (Glass, 1976; Schmidt, 2008; Schmidt \& Hunter, 1977)_focuses on quantitative empirical studies, and tends to bypass the large sets of qualitative studies found in many disciplines. The third of these (considerably rarer) methods is bibliometric analysis.

Bibliometrics (De Solla Price, 1965; Garfield, 1963; Pritchard, 1969) uses quantitative techniques such as clusterization and mapping in order to "catalog, classify and quantify knowledge in a given discipline" (Ferreira, Storopoli \& Serra, 2014, p. 112). In doing so, this methodology provides a 


\section{ARTICLE IN PRESS}

graphic and synthetic representation (Lee, Felps \& Baruch, 2014) of a research corpus, thus allowing researchers to focus on structures of recurring citation patterns (Arnott \& Pervan, 2012). This enables researchers to show, evaluate, and track the evolution of a research field or sub-field (Córdoba, Pilkington \& Bernroider, 2012; Raghuram, Tuertscher \& Garud 2010; Zupic \& Čater, 2013), to bring to light its theoretical pillars (e.g., International Management: Acedo \& Casillas, 2005; Relational Marketing: Chabowski, Samiee \& Hult, 2015; Information Systems Management: Culnan, 1986, 1987; Strategic Management: Nerur, Rasheed \& Natarajan, 2008) and to identify concept-, theory-, or model-building processes (e.g., Theories of Dynamic Competences: Di Stefano, Peteraf \& Verona, 2010; Strategic Management of Competences: Prévot, Branchet, Boissin, Castagnos \& Guieu, 2010; the Strategic Alignment Model: Renaud, Walsh, \& Kalika, 2016). We accordingly chose this approach in order to compare the development of the BM literature in the two main disciplines that have contributed to the concept's development: Strategic Management and Innovation \& Entrepreneurship.

Zupic and Čater (2015) have identified four commonly used bibliometric methods: citation and coauthor analysis, co-citation analysis (CCA), bibliographic coupling (BCA), and semantic analysis. Each of these methods holds its own principles and potential. That said, CCA and BCA are the most suitable approaches to tackle the issues raised in this article. The combination of CCA and BCA provides a complete overview since it offers a historical perspective of the literature. In doing so, we are able to comprehensively capture both the foundations and the current trends of the literature in question. ${ }^{1}$

1 Interestingly, only a handful of studies have applied these two techniques simultaneously (Kovacs, Van Looy \& Cassiman, 2015; Van Oorschot, Hofman \& Halman, 2015; Walsh \& Renaud, 2017). 


\section{ARTICLE IN PRESS}

\section{CO-CITATION ANALYSIS}

CCA enables one to investigate both the intellectual core of a research set and its invisible colleges (Crane, 1972; De Solla Price, 1965; Noma, 1984), i.e. groups of regularly co-cited documents that belong to the same research tradition. In turn, CCA can reveal the theoretical underpinnings and key assumptions that govern a particular research field. As these dynamics are particularly relevant to this study's research goals, we have employed CCA as a means of investigating the disciplinary specificities of the BM concept in terms of its theoretical foundations (RQ1).

CCA is based on the analysis of references cited in a scientific publication (Callon, Courtial \& Penan, 1993): two references (namely documents) or authors are said to be "co-cited" by another author when the latter cites them simultaneously (Small, 1973). This method relies on two central assumptions. First, the repetition of the citation of a pair of articles demonstrates the complementarity of these two articles (Callon et al., 1993), and second, researchers who co-cite the same references tend to share the same representation and perspective of their research domain (Small, 1973). From this perspective, the measure of similarity between two references or authors thus comes down to the frequency of co-citation in a selected area of scholarship (McCain, 1990). That said, many authors have criticized co-author citation for its assumption that any given author's entire output forms a coherent and homogeneous set (White \& Griffith, 1981). We agree that this assumption is problematic, as one author - through his/her intellectual development over timemay shift research themes or even perspectives on the same research topic. As such, here we have mobilized a CCA based on references.

The first stage of a CCA consists of a two-phase data collection process. First, the first-order sample is defined, namely the research corpus under investigation. The sole criterion here is that the query needs to correspond to the research project. For instance, when Nerur et al. (2008) sought to analyze 


\section{ARTICLE IN PRESS}

the Strategic Management field, they selected a set of articles published in Strategic Management journals. Two databases are available to researchers carrying out such queries: Scopus, developed by Elsevier, and Web of Science, developed by Thomson Reuters. These two databases are able to group together an important number of publications from most major research domains. Nevertheless, each has advantages and limitations (Adriaanse \& Rensleigh, 2013; Chadegani, et al., 2013; Harzing \& Alakangas, 2016); for practical reasons and issues of completeness, we selected Scopus for the present research.

Analyzing co-citations involves examining the references cited in the documents found in the firstorder sample. As it was not possible to include all of these references (several thousand), we built a second-order sample using the most frequently cited documents. This set is what Noma (1984) has elsewhere called an "intellectual core." More generally, this approach is based on the following assumption: the more a document is cited in a homogeneous literature, the more this document impacts the way that literature is constructed. The issue is thus to identify a frequency of citations that signals an article to be part of a given literature's intellectual core. De Solla Price (1965) argues that such bibliometric methods, while grounded in a quantitative analysis, must relinquish a certain degree of statistical rigor in order to enhance researchers' interpretations. Renaud et al. (2016) sum up this viewpoint in asserting that "the definition of the thresholds has to be processed through trial and error, striking a balance between statistical relevance and the significance of resulting data" (p. 79). That said, the larger the intellectual core, the more exhaustive the analysis; however, such an analysis will then suffer from considerable amount statistical noise, which paradoxically can impede interpretation. Conversely, the smaller the intellectual core, the higher the statistical relevance, which also restricts literature coverage. In terms of sample size, an examination of CCA 


\section{ARTICLE IN PRESS}

studies reveals that the average size of second-order samples falls between 30 and 50 references (Bayer, Smart \& McLaughlin, 1990; Di Stefano, et al., 2010; McCain, 1986, 1990).

The second stage of the CCA process is data processing. To begin with, the frequency of cocitations of the references in the second-order sample must be determined so as to build a square symmetric matrix, also called a "raw co-citation" matrix. Researchers have debated two main issues in this regard: what value to ascribe to the diagonal, and which normalization method to select. The first debate has largely been solved through the use of statistical software, but the second continue to split researchers into two opposing perspectives. The first one of these considers the co-citation matrix as self-sufficient, and hence as requiring no normalization (Ahlgren, Jarneving \& Rousseau, 2003; Leydesdorff \& Vaughan, 2006) given that the co-citation raw frequency is thought to accurately measure the similarity of any two articles. In contrast, the second perspective highlights the need to normalize due to the scale effect (Fernandez-Alles \& Ramos-Rodríguez, 2009). A wide range of normalization options have been used to do so, including Pearson's correlation coefficient (McCain, 1990), the cosine rule (Salton \& McGill, 1983), the Jaccard index (Jaccard, 1901), the Jensen-Shannon divergence (Lin, 1991), the inclusion index (Callon, et al., 1993), or the association strength measure (Van Eck \& Waltman, 2009). As we used VosViewer software (Van Eck \& Waltman, 2011; Waltman, Van Eck \& Noyons, 2010) for the present research, we chose to normalize our data with the software-integrated tool based on association strength.

The final stage of the CCA process relates to results visualization. In this regard, it is interesting to note that traditional statistical tools such as multidimensional scaling and principal cluster analysis (White \& McCain, 1998) have gradually declined in use following the emergence of network analysis visualization tools (Zupic \& Čater, 2015). Relatedly, VosViewer software provides three 


\section{ARTICLE IN PRESS}

benefits: it helps one to build and visualize this type of network while also allowing them to control a limited number of parameters; it supports large quantities of data; and it is free. Moreover, the software includes a powerful clustering tool based on Louvain's algorithm (Blondel, Guillaume, Lambiotte \& Lefebvre, 2008).

\section{BIBLIOGRAPHIC COUPLING ANALYSIS}

Developed by Kessler in 1960, BCA consists of the comparative analysis of references (or authors) cited in a corpus of documents. BCA relies on the assumption that the more two documents share cited references (or authors), the more consistent these two documents' perspectives will be. More specifically, the main assumption of BCA is the following: if two documents cite the same literature, they cover the same research themes, perspectives, and positioning. Accordingly, a given literature may be distributed into different clusters that constitute that literature's "research front" (Jarvening, 2005). In contrast with the CCA, BCA focuses the "current trend of research" instead of the "past traditions" in which these trends might be anchored (Vogel \& Güttel, 2013, p. 426). In the context of the present study, this technique enabled us to investigate the current BM research areas within the two disciplines in question with an eye on comparing them (RQ2).

The first stage of BCA is data collection. The literature being analyzed must be relatively homogeneous so as to facilitate the identification of its research front. The more consistent the sample is, the more its documents will share common references, and thus the easier the analysis will be. In this study, we used the same samples for both our CCA and our BCA. ${ }^{2}$ The second stage of BCA is to compute the bibliographic coupling indexes between each document. As discussed above, these bibliographic indexes are subject to scale effects (Van Eck \& Waltman, 2009) and

\footnotetext{
${ }^{2}$ In regard to CCA, we consider document BCA to be more relevant than author BCA in analyzing current research trends.
} 


\section{ARTICLE IN PRESS}

must therefore be normalized. As for our CCA, we used the association strength method proposed by VosViewer, and in turn computed the "total link strength index"3 for each document. The resulting first-order sample was sizable, and it was accordingly necessary to reduce the scope of our analysis so as to focus on documents that structured the research front, i.e. articles with a higher "total link" strength index. Following this, we identified three kinds of articles: (i) articles sharing many references with very few others (niche articles), (ii) articles sharing few references with many others (link articles), and (iii) articles sharing many references with many others (central articles). Following this, we determined the threshold of the sample through a trial and error process, striking a balance between statistical relevance and the significance of the resulting data (Zupic \& Čater, 2015). Finally, we split this research front into clusters using VosViewer.

\section{DATA COLLECTION AND ANALYSIS}

The purpose of this study is to compare the development of BM literature across two disciplines: Strategic Management and Innovation \& Entrepreneurship. To do so, we used CCA to identify the intellectual cores and theoretical pillars of both literatures. From there, BCA enabled us to map the research front of the literature and to highlight its main themes.

In establishing a first-order sample, we chose as our starting point a list of journals provided by the French National Center for Scientific Research (CNRS), as this list makes a key distinction between Strategic Management (22 journals) and Innovation \& Entrepreneurship (34 journals). We then used Scopus to search for any articles using the concept of "business model" in their title, abstract, and/or keywords. We also manually added relevant articles from journal websites that were missing from the CNRS list, then cleaned up the databases so as to ensure the accurate

\footnotetext{
${ }^{3}$ Consider three documents, $\mathrm{A}, \mathrm{B}$, and $\mathrm{C}$. If the $\mathrm{BC}$ index of $\mathrm{A}$ is respectively 0.4 and 0.3 with $\mathrm{B}$ and $\mathrm{C}$,
} then its total link strength is: $0.4+0.3=0.7$ 


\section{ARTICLE IN PRESS}

counting of references. Once the process had been completed, the sample was made up of 553 total articles. 345 of these were rooted in the Innovation \& Entrepreneurship literature, and consisted of 17,327 total references and 12,408 unique references (i.e. duplication removed). The remaining 208 articles came from Strategic Management, and included 8,926 references, of which 7,240 were unique (Table 1).

Table 1. First-order sample

\begin{tabular}{c|cc} 
& $\begin{array}{c}\text { Strategic } \\
\text { Management }\end{array}$ & $\begin{array}{c}\text { Innovation \& } \\
\text { Entrepreneurship }\end{array}$ \\
\hline \hline Articles & 208 & 345 \\
\hline References & 8,926 & 17,327 \\
\hline Unique references & 7,240 & 12,408
\end{tabular}

We then used VosViewer to identify our second-order sample. For CCA, the software includes (by default) any reference that is cited 20 times or more in the first-order sample within the "intellectual core." As explained above, bibliometrics disallows the arbitrary fixing of thresholds; hence, we selected the relevant thresholds through trial and error. We identified four potential thresholds in terms of two criteria: the citation rate of the reference in the first-order sample, and the size of the intellectual core obtained (Table 2).

Table 2. Second-order sample for CCA

\begin{tabular}{|c|c|c|}
\hline $\begin{array}{l}\% \text { of citations in the } \\
\text { first-order sample }\end{array}$ & $\begin{array}{c}\text { Strategic } \\
\text { Management } \\
(\mathbf{2 0 8 )}\end{array}$ & $\begin{array}{c}\text { Innovation \& } \\
\text { Entrepreneurship } \\
(345)\end{array}$ \\
\hline $8 \%$ & $\begin{array}{l}\text { \# min citations: } 16 \\
\text { Intellectual core: } 13\end{array}$ & $\begin{array}{l}\text { \# min citations: } 26 \\
\text { Intellectual core: } 29\end{array}$ \\
\hline $7 \%$ & $\begin{array}{r}\text { \# min citations: } 14 \\
\text { Intellectual core: } 19\end{array}$ & $\begin{array}{r}\# \text { min citations: } 23 \\
\text { Intellectual core: } 30\end{array}$ \\
\hline $6 \%$ & $\begin{array}{r}\text { \# min citations: } 12 \\
\text { Intellectual core: } 26\end{array}$ & $\begin{array}{r}\text { \# min citations: } 21 \\
\text { Intellectual core: } 36\end{array}$ \\
\hline $5 \%$ & $\begin{array}{l}\text { \# min citations: } 10 \\
\text { Intellectual core: } 36\end{array}$ & $\begin{array}{l}\text { \# min citations: } 16 \\
\text { Intellectual core: } 48\end{array}$ \\
\hline
\end{tabular}




\section{ARTICLE IN PRESS}

We rejected the $8 \%$ and $7 \%$ thresholds because the corresponding intellectual cores were too limited to make sense of (in terms of the averages found in the bibliometric work). We then analyzed and compared the results obtained with the other two thresholds. Finally, we decided that it would be more relevant to compare intellectual cores of the same size, and in turn chose to use citation thresholds of 5\% for Strategic Management and 6\% for Innovation \& Entrepreneurship, i.e. intellectual cores made up of 36 documents each.

In BCA, the software does not set an arbitrary threshold. Rather, the entire set of documents is analyzed, clustered, and mapped by default. We therefore decided to limit our analysis to those documents that shared the greatest number of references, in other words, a subset of highly consistent documents. We performed our analysis on three thresholds corresponding to the $10 \%$, $15 \%$, and $20 \%$ of the most consistent documents across the two literatures (Table 3 ).

\section{Table 3. Second-order sample for BCA}

\begin{tabular}{crr}
$\begin{array}{c}\text { \% of shared } \\
\text { references }\end{array}$ & $\begin{array}{c}\text { Strategic } \\
\text { Management } \\
\text { (208) }\end{array}$ & $\begin{array}{c}\text { Innovation \& } \\
\text { Entrepreneurship } \\
\mathbf{( 3 4 5 )}\end{array}$ \\
\hline \hline $\mathbf{2 0 \%}$ & \# of articles: 42 & \# of articles: 69 \\
\hline $\mathbf{1 5 \%}$ & \# of removed articles: 2 & \# of removed articles: 3 \\
\hline $\mathbf{1 0 \%}$ & \# of removed articles: 31 & \# of articles: 52 \\
\# of removed articles: 3
\end{tabular}

After carrying out a thorough analysis of the results for each research front, we concluded that the $15 \%$ threshold made the most sense to use in considering the Innovation \& Entrepreneurship (52 documents) and Strategic Management (31 documents) literatures. ${ }^{4}$

\footnotetext{
${ }^{4}$ Literature reviews tend to have a high proximity index with most of the investigated sets of articles, and consequently distort the results. Hence, we removed them from the analysis.
} 


\section{ARTICLE IN PRESS}

\section{ORIGINS AND TRENDS OF BUSINESS MODEL RESEARCH}

Drawing on a mixed bibliometric approach, we carried out a twofold comparison of the two key disciplines involved in $\mathrm{BM}$ research. Together, our CCA and BCA enabled us to compare the intellectual cores and theoretical pillars of the two disciplines (Appendix B), as well as their current research areas (Appendix C). Here, we first provide evidence that suggests a strong similarity between the two disciplines in terms of their intellectual cores and theoretical pillars. This demonstrates the conceptual consistency of the BM concept and the joint development of both literatures. Second, we provide evidence that reveals the specificity of the disciplines in terms of their current research areas, which simultaneously sheds light on the diversification of the BM literature.

\section{ORIGINS OF BUSINESS MODEL RESEARCH: A CO-CITATION ANALYSIS}

By applying CCA to the treatment of the BM concept in Strategic Management and Innovation \& Entrepreneurship research, we were able to identify two intellectual cores made up of 36 documents each, as well as two invisible colleges that are distributed into three similar clusters for both literatures (Appendix B). In this subsection, we provide a detailed comparative analysis of these intellectual cores and invisible colleges.

\section{Comparison of the intellectual cores}

These two intellectual cores represent the set of references on which the development of the concept of BM is based, and thus enable authors to legitimize and provide a rationale for their research. We carried out a threefold analysis of these intellectual cores. Firstly, we identified and analyzed references shared by both disciplines. Secondly, we focused on each discipline's specific references. Finally, we conducted a temporal analysis of the BM references in the intellectual cores. 


\section{ARTICLE IN PRESS}

\section{Shared references}

The first insight that came from our CCA relates to the similarity between the two intellectual cores: these cores share 26 out of 36 references, giving them a similarity rate of over $72 \%$. Table 4 lists these common references in terms of their disciplinary foundations ${ }^{5}$, a comparison that indicates that the two disciplines are clearly communicating with one another.

Table 4. Common references

\begin{tabular}{|c|c|c|c|}
\hline Authors & $\begin{array}{c}\text { Strategic } \\
\text { Management } \\
\end{array}$ & $\begin{array}{c}\text { Innovation \& } \\
\text { Entrepreneurship } \\
\end{array}$ & Other \\
\hline Amit \& Zott (2001) & $\mathrm{x}$ & & \\
\hline Baden-Fuller \& Morgan (2010) & $\mathrm{x}$ & & \\
\hline Barney (1991) & $\mathrm{x}$ & & \\
\hline Casadesus-Masanell \& Ricart (2010) & $\mathrm{x}$ & & \\
\hline Chesbrough \& Rosenbloom (2002) & $\mathrm{x}$ & & \\
\hline Demil \& Lecocq (2010) & $\mathrm{x}$ & & \\
\hline Johnson, Christensen \& Kagermann (2008) & $\mathrm{x}$ & & \\
\hline McGrath (2010) & $\mathrm{x}$ & & \\
\hline Porter (1980) & $\mathrm{x}$ & & \\
\hline Porter (1985) & $\mathrm{x}$ & & \\
\hline Sosna, Trevinyo-Rodriguez \& Velamuri (2010) & $\mathrm{x}$ & & \\
\hline Teece (2010) & $\mathrm{x}$ & & \\
\hline Teece, et al. (1997) & $\mathrm{x}$ & & \\
\hline Zott \& Amit (2008) & $\mathrm{x}$ & & \\
\hline Zott \& Amit (2010) & $\mathrm{x}$ & & \\
\hline Chesbrough (2003) & & $\mathrm{x}$ & \\
\hline Christensen (1997) & & $\mathrm{x}$ & \\
\hline Morris, Schindehutte \& Allen (2005) & & $\mathrm{x}$ & \\
\hline Osterwalder \& Pigneur (2010) & & $\mathrm{x}$ & \\
\hline Teece (1986) & & $\mathrm{x}$ & \\
\hline Zott \& Amit (2007) & & $\mathrm{x}$ & \\
\hline Eisenhardt (1989) & & & $\mathrm{x}$ \\
\hline Osterwalder, et al. (2005) & & & $x$ \\
\hline Shafer, et al. (2005) & & & $\mathrm{x}$ \\
\hline Yin (1984) & & & $\mathrm{x}$ \\
\hline Zott, et al. (2011) & & & $\mathrm{x}$ \\
\hline Total & $15(58 \%)$ & $6(23 \%)$ & 9\%) \\
\hline
\end{tabular}

${ }^{5}$ The classification of the references is based on journals' positioning according to the CNRS nomenclature, or, in the case of books, to the authors' home discipline. 


\section{ARTICLE IN PRESS}

In contrast with the idea that the conceptual heterogeneity of BM is inherited from certain "silos" (Zott, et al., 2011), this suggests that the development of the concept relies on equivalent theoretical foundations in both disciplines. Seen in this way, the idea of heterogeneity frequently asserted in the literature is more myth than reality.

The second insight revealed by this analysis concerns the BM literature's strong Strategic Management background. The two aforementioned intellectual cores are largely rooted in the Strategic Management literature (58\% of the citations), whereas the documents rooted in Innovation \& Entrepreneurship account for 23\%. References from other disciplines (Information Systems Management, General Management) thus account for less than 20\%. Consequently, it appears that the BM literature is largely built on the "classics" (Porter, 1980, 1985; Barney, 1991; Teece, Pisano \& Shuen, 1997) of the Strategic Management field.

We were also able to identify key authors within the intellectual core, i.e. authors who participate in the debates across both disciplines. These include Amit, Chesbrough, Osterwalder, Teece, Zott, and others. They act as boundary-spanners and contribute to the theoretical eclecticism of the literature. The most cited article of the BM research, "Business Models, Business Strategy and Innovation" (Teece, 2010), perfectly illustrates such a bridge between the two main disciplines.

To sum up, this analysis of common references reveals the strong similarity between both intellectual cores, as well as the inherent yet relative transdisciplinary nature of the BM literature.

\section{Specific references}

If one focuses on specific references across these disciplines, one notes a strong general theoretical background rooted in the Strategic Management literature, including few works from Innovation \& Entrepreneurship and other disciplines. Articles in the field of Strategic Management almost 


\section{ARTICLE IN PRESS}

exclusively cite works from their own discipline: $90 \%$ of the documents cited were published in the Strategic Management literature (Table 5).

Table 5. Specific references in the Strategic Management discipline

\begin{tabular}{lccc}
\hline \multicolumn{1}{c}{ Authors } & $\begin{array}{c}\text { Strategic } \\
\text { Management }\end{array}$ & $\begin{array}{c}\text { Innovation \& } \\
\text { Entrepreneurship }\end{array}$ & Other \\
\hline \hline Baden-Fuller \& Haefliger (2013) & $\mathrm{x}$ & \\
\hline Baden-Fuller \& Mangematin (2013) & $\mathrm{x}$ & \\
\hline Doz \& Kosonen (2010) & $\mathrm{x}$ & \\
\hline Johanson \& Vahlne (1977) & $\mathrm{x}$ & \\
\hline Magretta (2002) & $\mathrm{x}$ & \\
\hline Nelson \& Winter (1982) & $\mathrm{x}$ & \\
\hline Porter (1996) & $\mathrm{x}$ & \\
\hline Prahalad (2004) & $\mathrm{x}$ & \\
\hline Wernerfelt (1984) & $\mathrm{x}$ & $\mathrm{x}$ & \\
\hline Schumpeter (1934) & & $\mathbf{1}(\mathbf{1 0 \% )}$ & $\mathbf{0 ( 0 \% )}$ \\
\hline Total & $\mathbf{9 ( 9 0 \% )}$ &
\end{tabular}

Half of these references are seminal documents that have contributed to establishing the intellectual foundations of this reference discipline (Porter, 1996; Prahalad, 2004; Johanson \& Vahlne, 1977; Nelson \& Winter, 1982; Schumpeter, 1934; Wernerfelt, 1984). This not only shows the authors' intent to situate their work within a specific research stream - it also contributes to cementing the legitimacy of the concept of BM in the field.

Articles from the field of Innovation \& Entrepreneurship contain specific references mainly from Strategic Management (40\%) and research methodologies (40\%, “Other”) literatures. That said, works from the Innovation \& Entrepreneurship discipline itself represent only $20 \%$ of the specific references (Table 6).

While these results confirm the anchoring of BM research in Strategic Management, they also reveal a greater openness for BM research published in the Innovation \& Entrepreneurship literature, as well as the concept's relative transdisciplinarity. 


\section{ARTICLE IN PRESS}

Table 6. Specific references in the Innovation \& Entrepreneurship discipline

\begin{tabular}{lccc}
\hline \multicolumn{1}{c}{ Authors } & $\begin{array}{c}\text { Strategic } \\
\text { Management }\end{array}$ & $\begin{array}{c}\text { Innovation \& } \\
\text { Entrepreneurship }\end{array}$ & Other \\
\hline \hline Chesbrough (2006) & $\mathrm{x}$ & & \\
\hline Chesbrough (2010) & $\mathrm{x}$ & & \\
\hline Hamel (2000) & $\mathrm{x}$ & & \\
\hline Penrose (1959) & $\mathrm{x}$ & $\mathrm{x}$ & $\mathrm{x}$ \\
\hline George \& Bock (2011) & & $\mathrm{x}$ & $\mathrm{x}$ \\
\hline Markides (2006) & & & $\mathrm{x}$ \\
\hline Cohen \& Levinthal (1990) & & & $\mathrm{x}$ \\
\hline Eisenhardt \& Graebner (2007) & & $\mathbf{2 ( 2 0 \% )}$ & $\mathbf{4 ( 4 0 \% )}$ \\
\hline March (1991) & $\mathbf{4 ( 4 0 \% )}$ & \\
\hline Miles \& Huberman (1994) & & & \\
\hline Total & & & \\
\hline
\end{tabular}

\section{The temporal dimension of citation patterns}

From a temporal perspective, we found that the statistical weight of $\mathrm{BM}$ references in both intellectual cores follows the same pattern (see Figure 1). From 2000 to 2009, their cumulated volume slowly rose, albeit progressively. This period refers to the "introduction phase" of the BM literature.

Figure 1. The growing influence of the $\mathrm{BM}$ references in the intellectual cores

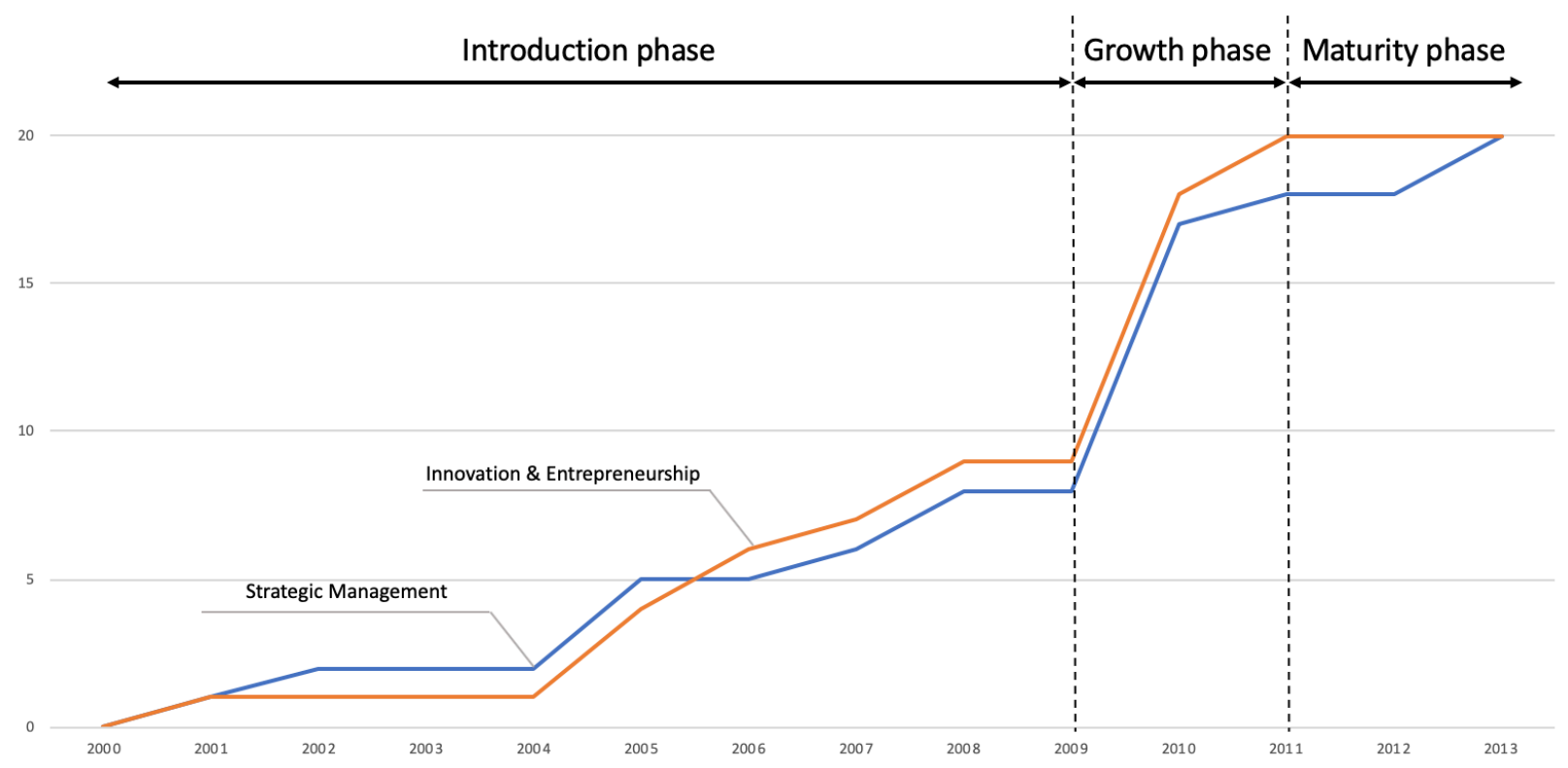




\section{ARTICLE IN PRESS}

From 2009 to 2011, we observe an explosion of such references, whose frequency increased by more than $100 \%$. This explosion is correlated with the publication of a special issue published in 2010 in Long Range Planning, which played a large role in the development and the legitimation of BM research. This period refers to the "(rapid) growth phase" of the literature. From 2011 to 2013, one can note a certain stagnation coupled with a high statistical weight of BM references, which demonstrates that at this point, BM literature had reached its "maturation phase."

\section{Comparison of the invisible colleges}

The invisibles colleges of both Strategic Management and Innovation \& Entrepreneurship literatures are composed of three and four clusters respectively (Appendix B). A graphic representation of these colleges can be found in Appendices D and E. ${ }^{6}$ Clusters 1, 2, and 3 of both disciplines share a high proportion of common references, thus providing evidence of their proximity. In light of this, we jointly labeled and interpreted each cluster as follows: theoretical grounding of the concept (Cluster Set 1); theoretical and practical legitimization of the concept (Cluster Set 2); and empowerment of the concept (Cluster Set 3).

\section{Cluster Set 1. Theoretical grounding of the concept}

Clusters 1SM (Strategic Management) and 1IE (Innovation \& Entrepreneurship), which together we call the "theoretical grounding of the concept," share $43 \%$ and $55 \%$ of common references, respectively. Cluster Set 1 refers to the theoretical foundations of the BM literature in both disciplines (Table 7).

\footnotetext{
${ }^{6}$ Graphic representations are useful in guiding researchers but are not sufficient per se for analyzing results. Interpreting results requires that researchers lend meaning to invisible colleges by exploring the references that make up the related clusters. In our case, our comparison of the composition of each discipline's clusters allowed us to assess their proximity to one another.
} 


\section{ARTICLE IN PRESS}

Table 7. Cluster Set 1: Theoretical grounding of the concept

\begin{tabular}{|c|c|}
\hline $\begin{array}{l}\text { 1SM. Strategic Management } \\
\text { (43\% in common) } \\
\end{array}$ & $\begin{array}{c}\text { 1IE. Innovation \& Entrepreneurship } \\
(55 \% \text { in common })\end{array}$ \\
\hline \multicolumn{2}{|c|}{ Shared references } \\
\hline \multicolumn{2}{|c|}{$\begin{array}{c}\text { Barney (1991) } \\
\text { Christensen (1997) } \\
\text { Porter (1980) } \\
\text { Porter (1985) } \\
\text { Teece (1986) } \\
\text { Teece, et al. (1997) }\end{array}$} \\
\hline \multicolumn{2}{|c|}{ Shared references in different clusters } \\
\hline $\begin{array}{l}\text { Eisenhardt }(1989)-\text { in cluster 4IE } \\
\text { Yin }(1989) \text { - in cluster 4IE }\end{array}$ & Chesbrough (2003) - in cluster $2 \mathrm{SM}$ \\
\hline \multicolumn{2}{|c|}{ Specific references } \\
\hline $\begin{array}{l}\text { Johanson \& Vahlne (1977) } \\
\text { Nelson \& Winter (1982) } \\
\text { Porter (1996) } \\
\text { Prahalad (2004) } \\
\text { Schumpeter (1934) } \\
\text { Wernerfelt (1984) }\end{array}$ & $\begin{array}{l}\text { Cohen \& Levinthal (1990) } \\
\text { Hamel (2000) } \\
\text { March (1991) } \\
\text { Penrose (1959) }\end{array}$ \\
\hline
\end{tabular}

More specifically, this cluster aims at overcoming the traditional dichotomies in both Strategic Management and Innovation \& Entrepreneurship literatures. A first subgroup of documents brings together the two main strategic perspectives on competitive advantage: the external Porterian approach (Porter, 1980, 1985, 1996) and the internal RBV approach (Barney, 1991; Penrose, 1959; Prahalad, 2004; Teece, et al., 1997; Wernerfelt, 1984). The BM concept offers a solution to the debate between these two perspectives by promoting an integrative approach that associates internal and external sources of value creation. The second subgroup, composed of documents from the Innovation \& Entrepreneurship field, relies primarily on a Schumpeterian perspective (Schumpeter, 1934) on firm performance as a means of promoting an integrative approach to processes of value creation and capture (Chesbrough, 2003; Christensen, 1997; Teece, 1986). By highlighting these debates, both disciplines accordingly position the BM concept as a renewed 


\section{ARTICLE IN PRESS}

means of overcoming traditional limitations, in large part by promoting an integrative perspective that emphasizes issues of internal/external fit and the creation/capture of value.

\section{Cluster Set 2. Theoretical and practical legitimization of the concept}

Clusters 2SM and 2IE relate to the "theoretical and practical legitimization of the concept," sharing $67 \%$ and $57 \%$ of cited references, respectively. In contrast with the first set of clusters, all of references for this second set belong directly to the BM literature. This Cluster Set deals with both the theoretical and practical legitimacy of the concept (Table 8).

Table 8. Cluster Set 2: Theoretical and practical legitimization of the concept

\begin{tabular}{c|c}
\hline $\begin{array}{l}\text { 2SM. Strategic Management } \\
(67 \% \text { in common) }\end{array}$ & $\begin{array}{c}\text { 2IE. Innovation \& Entrepreneurship } \\
\text { (57\% in common) }\end{array}$ \\
\hline \hline & Shared references \\
\hline & Amit \& Zott (2001) \\
Chesbrough \& Rosenbloom (2002) \\
Morris, et al. (2005) \\
Osterwalder, et al. (2005) \\
Shafer, et al. (2005) \\
\hline
\end{tabular}

Shared references in different clusters

Chesbrough (2003) - in cluster 1IE

Johnson, et al. (2008) - in cluster 3IE

Zott \& Amit (2007) - in cluster 3IE

Zott \& Amit (2008) - in cluster 3IE

Osterwalder \& Pigneur (2010) - in cluster 3SM

Specific references

\begin{tabular}{l|l}
\hline Magretta (2002) & Chesbrough (2006)
\end{tabular}

These legitimacies are mutually reinforcing, as scholars must typically anchor their work in current business issues while practitioners demand new frameworks for making good decisions. More specifically, it introduces a model for sources of value creation that is based on the concept of BM and that demonstrates its full potential in addressing performance-related issues (Amit \& Zott, 2001). By viewing the BM as a heuristic tool, the Cluster Set 2 details the logic of value capture for an emergent technology (Chesbrough \& Rosenbloom, 2002). The BM concept is particularly 


\section{ARTICLE IN PRESS}

useful here, as it enables one to simultaneously consider value creation and value capture processes.

The works making up Cluster Set 2 also lay many of the foundations for the first conceptualization of BM (Morris, Schindehutte, \& Allen, 2005; Osterwalder, et al., 2005; Shafer, et al., 2005).

\section{Cluster Set 3. Empowerment of the concept}

Clusters 3SM and 3IE, which together we call the "empowerment of the concept," respectively share $50 \%$ and $71 \%$ of cited references. Like the previous cluster set, these references are part of the BM literature, although on the whole are much more recent (Table 9).

Table 9. Cluster Set 3: Empowerment of the concept

\begin{tabular}{c|c}
\hline $\begin{array}{c}\text { 3SM. Strategic Management } \\
\text { (50\% in common) }\end{array}$ & $\begin{array}{c}\text { 3IE. Innovation \& Entrepreneurship } \\
\text { (71\% in common) }\end{array}$ \\
\hline \hline & Shared references \\
Baden-Fuller \& Morgan (2010) \\
Casadesus-Masanell \& Ricart (2010) \\
Demil \& Lecocq (2010) \\
McGrath (2010) \\
Sosna, et al. (2010) \\
Teece (2010) \\
Zott \& Amit (2010) \\
Zott, et al. (2011)
\end{tabular}

Shared references in different clusters

\begin{tabular}{l|l}
\hline Osterwalder \& Pigneur (2010) - in cluster 2IE & Johnson, et al. (2008) - in cluster 2SM \\
& Zott \& Amit (2007) - in cluster 2SM \\
Zott \& Amit (2008) - in cluster 2SM
\end{tabular}

Specific references

Baden-Fuller \& Haefliger (2013)

Baden-Fuller \& Mangematin (2013)

Doz \& Kosonen (2010)

Chesbrough (2010)

George \& Bock (2011)

Markides (2006)

Moreover, the articles of this Cluster Set were published in high impact factor journals, which contributes to the empowerment and structuration of the BM literature. Within these clusters, certain authors specify the positioning of the concept into strategy (Casadesus-Masanell \& Ricart, 2010) and innovation (Teece, 2010) fields, while others fine-tune its conceptual foundations 


\section{ARTICLE IN PRESS}

(Baden-Fuller \& Morgan, 2010; Zott, et al., 2011). Such definitional work is crucial to the empowerment of the research field, as it can give birth to what is known as the "key assumptions" about the new concept. Other studies here develop new theories about the BM in general (Amit \& Zott, 2010; McGrath, 2010) and its dynamics (Demil \& Lecocq, 2010; Sosna, et al., 2010). These scientific articles follow the path opened by the second Cluster Set and provide new insights regarding the issues raised in the first one.

\section{Cluster Set 4. Methodological sources}

Cluster 4IE - the only cluster in this fourth set-pertains to the literature's "methodological sources." This cluster relates solely to the discipline of Innovation \& Entrepreneurship. It is, therefore, highly connected with cluster 1SM (Table 10), in that it deals with the methodological choices that researchers have made in developing the BM concept. The empirical studies found therein are essentially based on case studies (Eisenhardt, 1989; Eisenhardt \& Graebner, 2017; Yin, 1984) and use qualitative data (Miles \& Huberman, 1994). In line with the double legitimation process described in Cluster Set 2, this cluster highlights both the practical orientation of the concept and the need for new theorizations.

Table 10. Cluster 4: Methodological sources

\begin{tabular}{c}
\hline $\begin{array}{c}\text { 4IE. Innovation \& Entrepreneurship } \\
(0 \% \text { in common })\end{array}$ \\
\hline Shared references in different clusters \\
\hline $\begin{array}{c}\text { Eisenhardt (1989) - in cluster 1SM } \\
\text { Yin (1989) - in cluster 1SM }\end{array}$ \\
Specific references \\
\hline
\end{tabular}

Eisenhardt \& Graebner (2007)

Miles \& Huberman (1994) 


\section{ARTICLE IN PRESS}

\section{Conclusion concerning CCA}

Our CCA enables us to make three robust arguments that answer the first research question (RQ1: What are the disciplinary specificities of the BM concept in terms of its theoretical foundations?), in that they effectively deal with the issue of heterogeneity: (1) the intellectual cores and theoretical pillars of both disciplines are similar; (2) the specific references mainly rely on both disciplines; (3) the BM literature's patterns of development across both disciplines are similar.

The strong similarity between the intellectual groundings of both disciplines demonstrates the conceptual consistency of the BM concept, which disproves both the idea of its "heterogeneity" and claims about its "silo-like" development (Zott, et al., 2011). Moreover, both literatures follow the same development pattern, which can be divided into three interrelated stages: theoretical background; theoretical and practical legitimization; and empowerment of the concept. Consequently, the idea of "convergence" (recently put forward by Wirtz, et al., 2016) hardly seems appropriate in characterizing the recent evolution of the concept. More specifically, we argue that this convergence has always existed, as the two main BM literatures follow the same pattern of development and share the same intellectual groundings. In fact, it seems to us that the preconceived notion of heterogeneity - itself based on disciplinary "silos" - has blinded BM research and led to a mistaken need for convergence, and consequently, to a counterproductive proliferation of synthetic works and definitions.

\section{TRENDS OF BUSINESS MODEL RESEARCH: A BIBLIOGRAPHIC COUPLING ANALYSIS}

By applying a BCA to the treatment of the BM concept, we were able to identify the current trends in the BM literature in both Strategic Management and Entrepreneurship \& Innovation disciplines (Appendix C). In this subsection, we describe these trends and compare them in order to 


\section{ARTICLE IN PRESS}

demonstrate that while the literatures have followed the same pattern of development, their research fronts - which illustrate their actual concerns - are different.

\section{Trends in the Strategic Management discipline}

The research front in the Strategic Management literature can be divided into two clusters, themselves based on two different BM ontologies. Cluster 1 refers to the essentialist approach of BMs (Table 11), whereas Cluster 2 relates to the cognitive perspective (Table 12).

The essentialist approach (Cluster 1; 17 articles) views BMs as the attributes of real firms. This traditional and mainstream conception is concerned with the process by which BMs create value (Achtenhagen, Melin, \& Naldi, 2013; Amit \& Zott, 2001; Casadesus-Masanell \& Ricart, 2010), BM change and innovation (Berghman, Matthyssens, Streukens \& Vandenbempt, 2013; Casadesus-Masanell \& Zhu, 2013; Casprini, Pucci \& Zanni, 2014; Demil \& Lecocq, 2010; Sosna, et al., 2010; Svejenova, Planellas \& Vives, 2010), BM internationalization (Breunig, Kvålshaugen \& Hydle, 2014; Maitland \& Sammartino, 2015; McQuillan \& Scott, 2015), social BMs (Sinkovics, Sinkovics \& Yamin, 2014; Yunus, Moingeon \& Lehmann-Ortega, 2010), and alternative definitions of BMs (Arend, 2013; Verstratete \& Jouison-Laffitte, 2011).

\section{Table 11. Cluster 1. Essentialist perspective}

\begin{tabular}{l|l}
\hline \multicolumn{2}{c}{ Cluster 1 (17 articles) } \\
\hline \hline Achtenhagen, et al. (2013) & Maitland \& Sammartino (2015) \\
Amit \& Zott (2001) & Mcquillan \& scott (2015) \\
Arend (2013) & Ricart, et al. (2004) \\
Berghman, et al. (2013) & Sinkovics, et al. (2014) \\
Breunig, et al. (2014) & Sosna, et al. (2010) \\
Casadesus-Masanell \& Ricart (2010) & Svejenova, et al. (2010) \\
Casadesus-Masanell \& Zhu (2013) & Verstraete, et al. (2011) \\
Casprini, et al. (2014) & Yunus, et al. (2010) \\
Demil \& Lecocq (2010) &
\end{tabular}




\section{ARTICLE IN PRESS}

Cluster 2 (12 articles) is comprised of articles that share a cognitive perspective on BMs, much in line with the legacy of Baden-Fuller and Morgan (2010). This approach views BMs as "models" that provide descriptions and classifications (Baden-Fuller \& Haelfliger, 2013; Rumble \& Mangematin, 2015) or that operate as sites for scientific investigation (Zhang, Lichtenstein \& Gander, 2015) or as recipes for managers (Aspara, Lamberg, Laukia \& Tikkanen, 2013; Hienerth, Keinz \& Lettl, 2011). For their part, Baden-Fuller and Mangematin (2013) explore the BM as a set of cognitive configurations or maps (Furnari, 2015) that can be manipulated and modularized by managers (Aversa, Haefliger, Rossi \& Baden-Fuller, 2015). The development of a new research agenda dedicated to the cognitive perspective has also been put forward, within which certain scholars have thought it fruitful to investigate BM dynamics (Van den Oever \& Martin, 2015) and BM innovation (Waldner, Poetz, Grimpe \& Eurich, 2015).

Table 12. Cluster 2. Cognitive perspective

\begin{tabular}{l|l}
\hline \multicolumn{2}{c}{ Cluster 2 (12 articles) } \\
\hline \hline Aspara, et al. (2013) & Hienerth, et al. (2011) \\
Aversa, et al. (2015) & Kodama (2009) \\
Baden-Fuller \& Haefliger (2013) & Rumble \& Mangematin (2015) \\
Baden-Fuller \& Mangematin (2013) & Van Den Oever \& Martin (2015) \\
Baden-Fuller \& Morgan (2010) & Waldner, et al. (2015) \\
Furnari (2015) & Zhang, et al. (2015)
\end{tabular}

The analysis of these two clusters provides evidence of the existence of a mainstream traditional approach: the essentialist perspective. The average date of publication for articles in Cluster 1 is roughly 2011, which corresponds to the transition between the "rapid growth" and "maturity" phases of BM research. This approach has been the subject of the vast majority of the publications that deal with BMs. In considering the inherent limitations of this essentialist approach, some authors (Baden-Fuller \& Mangematin, 2013; Doganova \& Eyquem-Renault, 2009) have promoted 


\section{ARTICLE IN PRESS}

a new perspective and a research agenda based on a cognitive approach to BMs, both aimed at investigating a number of challenging issues in more depth, including BM design in emerging firms, the emergence of new BMs in mature firms, and more generally BM innovation. On average, the articles in Cluster 2 were published in 2013, a date that corresponds to the "maturity" phase of $\mathrm{BM}$ research. During this period, researchers can be seen proposing new approaches aimed at diversifying and enriching the content of the literature.

Relatedly, we observe that the literature is still relatively locked in a conceptual debate in which one approach is set against the other. This debate largely considers a BM to be a theoretical object rather than a heuristic that can be used to address topical issues. This is consistent with the analysis provided in our introduction concerning the literature's concentration on defining BMs. It also accounts for the existence of a pool of highly cited authors in these clusters, which can be understood as having laid the foundations for the concept itself: Amit; Baden-Fuller; CasadesusMasanell; Demil; Lecocq; Ricart; Zott; etc. (cf. Cluster Set 3, "empowerment of the concept," Table 9). In light of this, the dynamics of the literature must be strengthened with the aim of overcoming the esoteric debates about BM ontology and of thus producing research that is more receptive to real-life preoccupations. To this end, special issues could play a valuable role in opening new publication spaces dedicated to trending topics.

\section{Trends in the Innovation \& Entrepreneurship discipline}

The research front of the BM literature in Innovation \& Entrepreneurship is structured around five research issues: $\mathrm{BM}$ innovation, $\mathrm{BM}$ capabilities, open innovation, disruption and industry dynamics, and customer-oriented BMs.

Cluster 1 (9 articles) refers to BM innovation in general. These articles cover the external pressures that influence BM innovation and change, such as exogenous discontinuous innovation (Ghezzi, 


\section{ARTICLE IN PRESS}

Cavallaro, Rangone \& Balocco, 2015), venture capital firms and outside CEOs (Gerasymenko, De Clercq \& Sapienza, 2015), industry-dominant logics (Obloj, Obloj \& Pratt, 2010), or the specificities of emerging markets (Landau, Karna \& Sailer, 2016). This cluster also deals with internal drivers, such as dynamic capabilities (Mezger, 2014), strategic flexibility (Schneider \& Spieth, 2014), resource sharing (Cardeal, Abecassis-Moedas \& Antonio, 2014), managerial cognition (Osiyevskyy \& Dewald, 2015), and imitation processes (Enkel \& Mezger, 2013).

Table 13. Cluster 1. Business Model Innovation

\begin{tabular}{l|l}
\hline \multicolumn{2}{c}{ Cluster 1 (9 articles) } \\
\hline \hline Cardeal, et al. (2014) & Mezger (2014) \\
Enkel \& Mezger (2013) & Obloj, et al. (2010) \\
Gerasymenko et al. (2015) & Osiyevskyy \& Dewald (2015) \\
Ghezzi, et al. (2015) & Schneider \& Spieth (2014) \\
Landau, et al. (2016) &
\end{tabular}

Cluster 2 (11 articles) is composed of articles concerned with BM capabilities. It focuses on the role of internal (Andries \& Debackere, 2013; Bicen \& Johnson, 2015; Cucculelli \& Bettinelli, 2015) and external (Miller, Mcadam \& Mcadam, 2014; Tasavori, Zaefarian \& Ghauri, 2015) capabilities in BM innovation. Conversely, these articles cover the role of a BM itself in developing the capabilities needed to build an emerging (Doganova \& Eyquem-Renault, 2009; Trimi \& Berbegal-Mirabent, 2012) or a sustainable (Carayannis, Sindakis \& Walter, 2015) company. The cluster also deals with how dual BMs can be ambidextrously managed via capabilities linkages (Winterhalter, Zeschky \& Gassmann, 2016). Finally, the cluster covers the connections between BM capabilities and performance (Mustar, et al., 2006; Schindehutte, Morris \& Kocak, 2008). 


\section{ARTICLE IN PRESS}

Table 14. Cluster 2. Business Model Capabilities

\begin{tabular}{l|l}
\hline \multicolumn{2}{c}{ Cluster 2 (11 articles) } \\
\hline \hline Andries \& Debackere (2013) & Mustar, et al. (2006) \\
Bicen \& Johnson (2015) & Schindehutte, et al. (2008) \\
Carayannis, et al. (2015) & Tasavori, et al. (2015) \\
Cucculelli \& Bettinelli (2015) & Trimi \& Berbegal-Mirabent (2012) \\
Doganova \& Eyquem-Renault (2009) & Winterhalter, et al. (2016) \\
Miller, et al. (2014) &
\end{tabular}

The third cluster (13 articles) refers to the concept of open innovation. The authors represented in this cluster view this theme from different angles: open BMs as BMs for patent-aggregating companies (Krech, Ruther \& Gassmann, 2015), open-service innovation (Mina, BascavusogluMoreau \& Hughes, 2014), and collaborations (Denicolai, Ramirez \& Tidd, 2014) through coopetition (Brolo, 2009), networks and communities (Kodama, 2007). This cluster deals with the antecedents (Frankenberger, Weiblen \& Gassmann, 2014), the front-end and back-end processes (Bogers, Hadar \& Bilberg, 2016; Gunzel \& Holm, 2013), and the effects (Holm, Gunzel \& Ulhoi, 2013) of open BMs. Moreover, these studies also address the organizational specificities (Herzog \& Leker, 2010) and the performance (Braun, 2015) of open BMs, even in the context of misfit technology (Anokhin, Wincent \& Frishammar, 2011).

Table 15. Cluster 3. Open Innovation

\begin{tabular}{l|l}
\hline \multicolumn{2}{c}{ Cluster 3 (13 articles) } \\
\hline \hline Anokhin, et al. (2011) & Herzog \& Leker (2010) \\
Bogers, et al. (2016) & Holm, et al. (2013) \\
Braun (2015) & Kodama (2007) \\
Brolo (2009) & Krech, et al. (2015) \\
Denicolaï, et al. (2014) & Mina, et al. (2014) \\
Frankenberger, et al. (2014) & Scaringella (2014) \\
Gunzel \& Holm (2013) &
\end{tabular}




\section{ARTICLE IN PRESS}

Cluster 4 (8 articles) focuses on disruption and industry dynamics. It deals with the implications of BM innovation for the performance of incumbents (Kim \& Min, 2015) and new entrants (Velu, 2015). More specifically, the cluster focuses on the antecedents and effects of disruption (Wan, Williamson \& Yin, 2015), be it technology- or market-driven (Habtay, 2012). Certain of this clusters' authors also provide an analysis of how disruption can generate different types of incumbent responses (Bergek, Berggren, Magnusson \& Hobday, 2013; Hebtay \& Holmen, 2014; Khanagha, Volberda \& Oshri, 2014), as well as how disruption may challenge the dominant logic of an industry (Sabatier, Craig-Kennard \& Mangematin, 2012).

Table 16. Cluster 4. Disruption and Industry Dynamics

\begin{tabular}{l|l}
\hline \multicolumn{2}{c}{ Cluster 4 (8 articles) } \\
\hline \hline Bergek, et al. (2013) & Kim \& Min (2015) \\
Habtay (2012) & Sabatier, et al. (2012) \\
Habtay \& Holmen (2014) & Velu (2015) \\
Khanagha, et al. (2014) & Wan, et al. (2015)
\end{tabular}

Cluster 5 (8 articles) is primarily concerned with customer-oriented BMs. These articles center on the service economy, providing an analysis of the links between service BMs and service innovativeness (Cheng, Shiu \& Dawson, 2014), service-dominant logic and the BM concept (Clauss, Laudien \& Daxbock, 2014), and technology shifts and service innovation (Tongur \& Engwall, 2014) or BM design (Wei, Yang, Sun \& Gu, 2014). The cluster also sheds light on the inclusion of customers (Spickermann, Grienitz \& Von Der Gracht, 2014) or partners (Rohrbeck, Konnertz \& Knab, 2013) in the business-modelling process. Elsewhere, it addresses the issue of BM market fit through the classification of BM patterns (Abdelkafi, Makhotin \& Posselt, 2013) or the commercialization of technology innovations (Dmitriev, Simmons, Truong, Palmer \& Schneckenberg, 2014). 


\section{ARTICLE IN PRESS}

Table 17. Cluster 5. Customer-oriented Business Models

\begin{tabular}{l|l}
\hline \multicolumn{2}{c}{ Cluster 5 (8 articles) } \\
\hline \hline Abdelkafi, et al. (2013) & Rohrbeck, et al. (2013) \\
Cheng, et al. (2014) & Spickermann, et al. (2014) \\
Clauss, et al. (2014) & Tongur \& Engwall (2014) \\
Dmitriev, et al. (2014) & Wei, et al. (2014)
\end{tabular}

Our analysis of these five clusters revealed the diversity — as well as the global consistency —of the perspectives adopted by scholars to deal with BM innovation in general (Cluster 1). In it, we first considered both the internal and external issues of BM innovation: Cluster 2 can be said to deal with the capabilities needed to innovate, whereas Cluster 4 is more concerned with the effects of BM innovation in an industry. Second, we highlighted various types of innovative BMs under investigation: for instance, open BMs (Cluster 3) and customer-oriented BMs (Cluster 5). Both clusters are concerned with the inclusion of external partners, calling into question the boundaries of firms in the context of BM innovation. In sum, this analysis reveals the maturity of the BM research in the Innovation \& Entrepreneurship literature and highlights the role that it plays in the diversification of the themes addressed by the BM literature.

Indeed, in contrast with the Strategic Management literature, the Innovation \& Entrepreneurship literature has nurtured, as a matter of priority, the development of topical issues directly connected to managers' concerns. For instance, the articles of Clusters 1, 2, and 4 provide insights into the antecedents and effects of BM innovation; Clusters 3 and 5 offer guidelines for managers to deal with the inclusion of external actors. We believe that the Innovation \& Entrepreneurship literature remains one step ahead of Strategic Management literature, as it is able to build on different conceptual perspectives in order to develop original research rooted in managers' and entrepreneurs' concerns. For their part, Sabatier et al. (2012) draw on the essentialist approach of BMs in analyzing the link between technological discontinuities and disruption, whereas 


\section{ARTICLE IN PRESS}

Osiyevskyy and Dewald (2015) rely on the cognitive perspective to study the antecedents of firmlevel responses to disruptive innovation. In these ways, the Innovation \& Entrepreneurship literature has moved beyond the outdated conceptual debate, instead viewing the BM as a heuristic tool that can be used to address practical issues.

\section{Conclusion concerning BCA}

Our BCA provides three robust responses to our second research question (RQ2: What are the disciplinary specificities of the BM concept in terms of its current research areas?): across the two literatures, current research areas are structured differently (two vs. five clusters); the status of the concept is not the same (research object vs. research tool); and the degree of maturity differs (definition phase vs. theorization phase). Moreover, our global analysis of the trends in both literatures revealed strong discipline-based specificities. On the one hand, the Strategic Management literature is structured around two perspectives of the BM, themselves based on two distinct ontologies. On the other hand, the Innovation \& Entrepreneurship literature is organized around five consistent issues related to BM innovation. Nevertheless, one can note several connections between these two disciplines. For instance, BM innovation-a central topic of the Innovation \& Entrepreneurship literature - is becoming a significant area of research in Strategic Management, largely thanks to scholars' interest in the cognitive approach, itself particularly appropriate for the study BM dynamics and evolution.

\section{DISCUSSION}

The BM literature is developing rapidly and requires regular assessment. In this vein, dozens of literature reviews and essays were published between 2003 and 2017 (Appendix A). For many of these, researchers adopt a transdisciplinary perspective; however, while such articles recognize 


\section{ARTICLE IN PRESS}

contributions of different disciplines (Al-Debei \& Avison, 2010) or "silos" (Zott, et al., 2011), the research outcomes remain generic and largely fail to highlight the specificities of the various disciplines actively investigating the concept. Moreover, their conclusions remain heterogeneous and actually fuel the existing debate (Klang, et al., 2014).

The research objective of this article has been to identify the disciplinary specificities of the BM concept by covering two kinds of heterogeneity: One on the "origins" of the concept and the other on its "trends." Our guiding assumption was that added nuance could lead to a clearer understanding of the concept's hidden dynamics, and more broadly, of the development of the field. To do so, we compared the contributions of the two main scientific disciplines involved in the development of the BM literature: Strategic Management and Innovation \& Entrepreneurship.

Our subsequent CCA demonstrates that the theoretical groundings of BM concept were similar in both disciplines (RQ1). Hence, the apparent heterogeneity of definitions round in the research (Wirtz, et al., 2016; Zott, et al., 2011) is not a product of some "fragmented development" within the literature. Conversely, we hold that the BM concept has been jointly built and legitimized by both Strategic Management and Innovation \& Entrepreneurship literatures; indeed, authors from these disciplines cite the same references, regardless of their scientific tradition. In this way, this study provides scientific evidence that supports Baden-Fuller and Mangematin's (2013) claim that there exists a general agreement in the literature regarding the definition of a BM. In fact, the "heterogeneity" of the concept appears to be socially constructed (Gulati, 2007) and highly subject to researchers' language games (Klang, et al., 2014) and terminology preferences (Foss \& Saebi, 2017), and not the consequence of "fragmented" development. This heterogeneity can thus be explained by researchers' mobilization of different degrees of terminological nuance (regarding economic value, revenues, benefits, money, and so on), their use of synonyms (e.g. interlocking, 


\section{ARTICLE IN PRESS}

articulates, interrelated, connects), or even their choice of perspectival orientation (e.g. customeroriented vs. organization-oriented).

Moreover, our CCA results show that the BM literature follows a single pattern of development regardless of discipline, based on a threefold maturity process. The first level (Cluster Set 1) shows that the concept emerged to transcend two dichotomies in its reference disciplines. The second level (Cluster Set 2), for its part, indicates that the BM literature is still close to its reference disciplines but, simultaneously, is involved in a practical and academic legitimation process. The third maturity level (Cluster Set 3) finally reveals that the BM literature is self-supporting and goes beyond the legitimacy issue to focus on the refinement of the concept and related-theorizations. Through these results, we show that the BM literature as a whole is currently in a phase of empowerment, as it tends to refer to itself.

Still, our BCA reveals strong differences between the research fronts of the two disciplines, namely their main areas of research (RQ2). While Wirtz et al. (2016) have asserted that the BM literature trends towards convergence, our results indicate a series of far more complex dynamics. Despite the homogeneous theoretical roots of BM research, this study demonstrates that both disciplines employ the concept differently and that its development has two distinct trajectories.

The Strategic Management literature is structured into two main clusters that bring together articles sharing two ontological perspectives on BMs: "essentialist" vs. "cognitive." Here, we can note that three subthemes are currently emerging within research based in the essentialist ontology: BM internationalization, social BMs, and processes of value creation. Elsewhere, we find that BM innovation and emergence processes are more prevalent in work adopting the cognitive perspective. Nevertheless, these various subthemes are not sufficiently grounded, and thus do not 


\section{ARTICLE IN PRESS}

form autonomous BM research streams. From this, we can safely conclude that there is an ongoing, implicit debate regarding the BM definition in the Strategic Management literature.

The Innovation \& Entrepreneurship literature is structured around five general themes: open innovation, BM capabilities, BM innovation, customer-oriented BMs, and disruption and industry dynamics. These themes belong to topical research areas in the discipline. In contrast to the Strategic Management literature, articles in this discipline are not differentiated from one another through an ontology, but rather, seem based on specific issues within the discipline. As such, the Innovation \& Entrepreneurship literature follows a different yet complementary logic, as the theoretical and managerial issues prevail on ontological debates.

Given these complexities, our mixed bibliometric analysis effectively sheds light on the history of BM research. Contrary to perceptions found in the literature, our CCA shows that a common conception of BM has prevailed from the onset of this research stream since it is built on shared theoretical and intellectual pillars. Moreover, our BCA demonstrates that both disciplines are clustered into specific perspectives. In these ways, the BM literature is already incredibly diverse on both the disciplinary (clusterization) and transdisciplinary (disciplines cross-fertilization) levels. The mixed bibliometric method employed in this study provides further evidence for the cumulative development of BM research.

With these dynamics in mind, we maintain that two developmental strategies will facilitate the development of future BM-related research. First, disciplines should cross-fertilize in order to enrich their own conceptualization and reinforce the co-development of their respective fields. For example, disciplines could combine their efforts in developing transversal issues, such as BM innovation in general. Second, disciplines should continue to diversify the concept of BM on the basis of their specific thematics. For example, while the Innovation \& Entrepreneurship literature 


\section{ARTICLE IN PRESS}

is already engaged in this dynamic, the Strategic Management literature might consider classic issues (e.g. internationalization, performance, strategy implementation) through the lens of BMs. Figure 2 illustrates these two developmental strategies.

Figure 2. Twofold strategy for BM research development

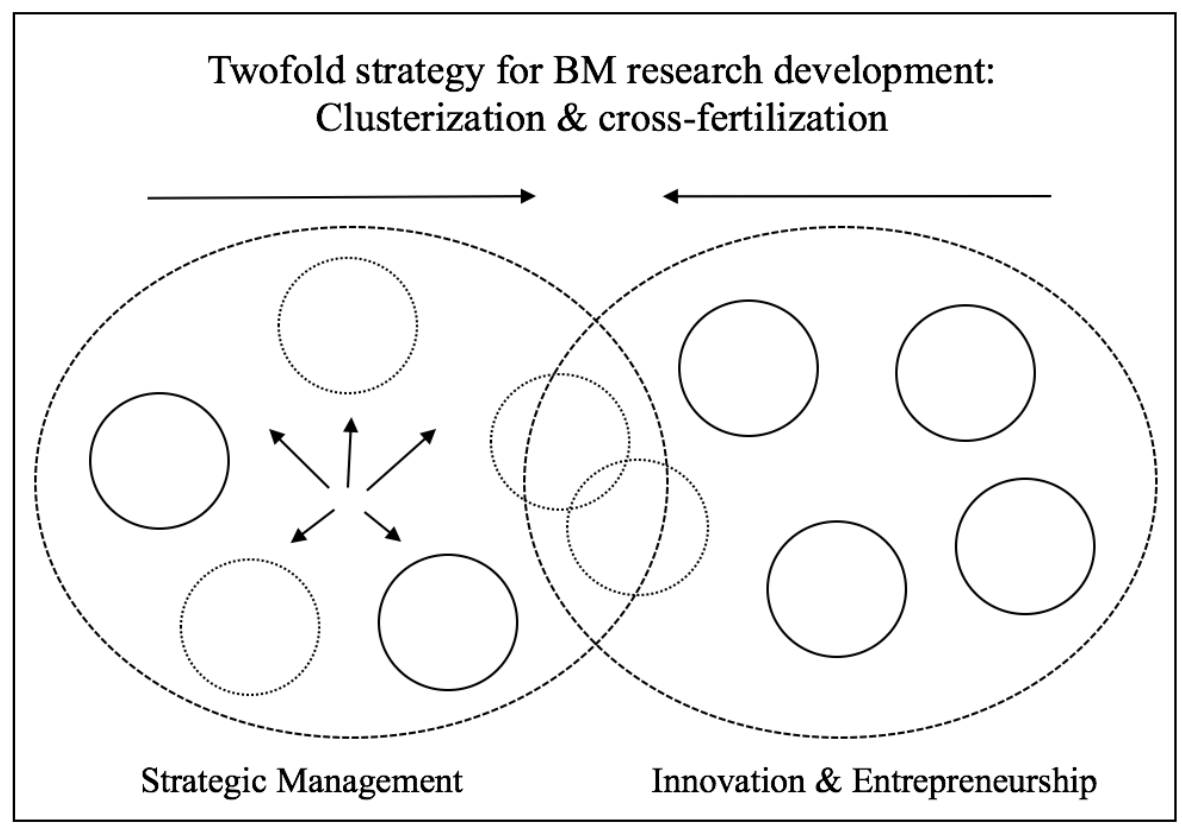

These two strategies must be supported by intensive institutional work. Examples of this include the first Business Model Conferences and the Journal of Business Models, both of which contribute to the institutionalization of the BM literature. In the future, special issues on BMs would help the literature to become more structured, as they would couple BM-related research with other emerging issues (and thus constitute future clusters for the research front of BM scholarship). The special issues published in Long Range Planning (2010) and M@n@gement (2010)—which supported the essentialist perspective in Strategic Management literature-as well as those in Advances in Strategic Management (2015) and the Strategic Entrepreneurship Journal (2015)— which developed the cognitivist approach — were outstanding initiatives in this regard, and similar ones should be considered in the decades to come. 


\section{ARTICLE IN PRESS}

\section{CONCLUSION}

By drawing on bibliometric analyses, we have provided evidence concerning the disciplinary specificities of the BM literature. The contributions of this study are threefold. Firstly, it lends heightened nuance to our understanding of the development of the BM literature and provides a more historical perspective on its origins. More specifically, our analyses identify the theoretical pillars of BMs that are common to both the Strategic Management and Innovation \& Entrepreneurship literatures. Moreover, these analyses highlight the specificities of each literature's research front, thus qualifying the commonly held belief regarding the convergence of perceptions on BM. Secondly, we have made two strategy recommendations aimed at facilitating both development of the literature and its institutionalization as an autonomous field of research. The first of these strategies relies on the development of synergies between the two disciplines, whereas the second encourages the diversification of the disciplines on the basis of specific thematics. The third contribution of this study is methodological: by combing two bibliometric methods (CCA and BCA) (as suggested by Walsh \& Renaud, 2017), we were able to obtain a finegrained analysis of the hidden dynamics of the scientific literature on BMs. This approach complements more traditional literature reviews on the concept published in recent decades.

The limitations of this study provide exciting opportunities for future related research. From a methodological perspective, future work could integrate other disciplines that contribute in a notable way to the BM literature (e.g. Marketing, Information Systems Management), thus complementing and enriching our results and the present discussion. Furthermore, while the BM literature has reached its maturity phase, our analyses do not provide an in-depth examination of the dynamics that have contributed to its development. We thus encourage scholars to further analyze how the BM literature has been shaped over time and across disciplines. Such research 


\section{ARTICLE IN PRESS}

would be an important step forward, in that it would contribute to establishing the BM literature as an autonomous field of research.

Despite these limitations, this article is the first exhaustive analysis of the BM literature that covers the concept's past, present, and future. As such, it establishes a starting point for newcomers to the conversation, particularly insofar as it explores the prolific BM literature and overcomes a number of counterproductive conceptual debates found therein. Moreover, it offers guidance for accurately positioning research initiatives alongside of current and emerging scientific conversations. In a broader sense, it thus provides evidence for the maturity of the concept and paves the way for future reflections on this rich literature, which has quickly emerged as a critical and fascinating stream of management research.

\section{REFERENCES}

Acedo, F.J. \& Casillas, J.C. (2005). Current Paradigms in the International Management Field: An Author Co-Citation Analysis. International Business Review, 14(5), 619-639.

Adriaanse, S.L. \& Rensleigh, C. (2013). Web of Science, Scopus and Google Scholar: A Content Comprehensiveness Comparison. The Electronic Library, 31(6), 727-744.

Ahlgren, P., Jarneving, B. \& Rousseau, R. (2003). Requirement for a Cocitation Similarity Measure, with Special Reference to Pearson's Correlation Coefficient. Journal of the American Society for Information Science and Technology, 54(6), 550-560.

Al-Debei, M.M. \& Avison, D. (2010). Developing a Unified Framework of the Business Model Concept. European Journal of Information Systems, 19(3), 359-376.

Arnott, D. \& Pervan, G. (2012). Design Science in Decision Support Systems Research: An Assessment Using the Hevner, March, Park, and Ram Guidelines. Journal of the Association for Information Systems, 13(11), 923-949.

Baden-Fuller, C., Demil, B., Lecocq, X. \& MacMillan, I.M. (2010). Editorial. Long Range Planning, 43(2-3), 143-145.

Baden-Fuller, C. \& Mangematin, V. (2013). Business Models: A Challenging Agenda. Strategic Organization, 11(4), 418-427.

Baden-Fuller, C. \& Morgan, M.S. (2010). Business Models as Models. Long Range Planning, 43(2), 156-171. 


\section{ARTICLE IN PRESS}

Bayer, A.E., Smart, J.C. \& McLaughlin, G.W. (1990). Mapping Intellectual Structure of a Scientific Subfield through Author Cocitations. Journal of the American Society for Information Science, 41(6), 444-452.

Boons, F. \& Lüdeke-Freund, F. (2013). Business Models for Sustainable Innovation: State-of-theart and Steps towards a Research Agenda. Journal of Cleaner Production, 45, 9-19.

Callon, M., Courtial, J.P. \& Penan, H. (1993). La scientométrie. Presse Universitaire de France, Paris.

Chadegani, A., Salehi, H., Yunus, M.M., Farhadi, H., Fooladi, M., Farhadi, M. \& Ale Ebrahim, N. (2013). A Comparison between Two Main Academic Literature Collections: Web of Science and Scopus Databases. Asian Social Science, 9(5), 18-26.

Córdoba, J.R., Pilkington, A. \& Bernroider, E.W. (2012). Information Systems as a Discipline in the Making: Comparing EJIS and MISQ between 1995 and 2008. European Journal of Information Systems, 21(5), 479-495.

Crane, D., 1972. Invisible Colleges: Diffusion of Knowledge in Scientific Communities. University of Chicago Press, 224p.

Culnan, M.J. (1986). The Intellectual Development of Management Information Systems, 19721982: A Co-Citation Analysis. Management Science, 32(2), 156-172.

Culnan, M.J. (1987). Mapping the Intellectual Structure of MIS, 1980-1985: A Co-Citation Analysis. MIS Quarterly, 11(3), 341-353.

De Solla Price, D.J. (1965). Networks of Scientific Papers. Science, 149(3683), 510-515.

Demil, B., Lecocq, X., Ricart, J.E. \& Zott, C. (2015). Introduction to the SEJ Special Issue on Business Models: Business Models within the Domain of Strategic Entrepreneurship. Strategic Entrepreneurship Journal, 9(1), 1-11.

Demil, B. \& Lecocq, X. (2010). Business Model Evolution: in Search of Dynamic Consistency. Long Range Planning, 43(2), 227-246.

Di Stefano, G., Peteraf, M. \& Verona, G. (2010). Dynamic Capabilities Deconstructed: A Bibliographic Investigation into the Origins, Development, and Future Directions of the Research Domain. Industrial and Corporate Change, 19(4), 1187-1204

Doganova, L. \& Eyquem-Renault, M. (2009). What Do Business Models Do? Innovation Devices in Technology Entrepreneurship. Research Policy, 38(10), 1559-1570.

Fernandez-Alles, M. \& Ramos-Rodríguez, A. (2009). Intellectual Structure of Human Resources Management Research: A Bibliometric Analysis of the Journal Human Resource Management, 1985-2005. Journal of the American Society for Information Science and Technology, 60(1), 161175.

Ferreira, M.P., Storopoli, J.E. \& Serra, F.R. (2014). Two Decades of Research on Strategic Alliances: Analysis of Citations, Co-Citations and Themes Researched. Revista de Administração Contemporânea, 18(SPE), 109-133.

Foss, N.J. \& Saebi, T. (2017). Fifteen Years of Research on Business Model Innovation: How Far Have We Come, and Where Should We Go? Journal of Management, 43(1), 200-227. 


\section{ARTICLE IN PRESS}

Garfield, E. (1963). Citation Indexes in Sociological and Historical Research. American documentation, 14(4), 289-291.

Garfield, E. (1979). Is Citation Analysis a Legitimate Evaluation Tool? Scientometrics, 1(4), 359375.

Glass, G.V. (1976). Primary, Secondary, and Meta-Analysis of Research. Educational Researcher, 5(10), 3-8.

Gulati, R. (2007). Tent Poles, Tribalism, and Boundary Spanning: The Rigor-Relevance Debate in Management Research. Academy of Management Journal, 50(4), 775-782.

Harzing, A.W. \& Alakangas, S. (2016). Google Scholar, Scopus and the Web of Science: A Longitudinal and Cross-disciplinary Comparison. Scientometrics, 106(2), 787-804.

Hedman, J. \& Kalling, T. (2003). The Business Model Concept: Theoretical Underpinnings and Empirical Illustrations. European Journal of Information Systems, 12(1), 49-59.

Jaccard, P. (1901). Bulletin de la Société Vaudoise des Sciences Naturelles. 37, 241-272.

Jarneving, B. (2005). A Comparison of Two Bibliometric Methods for Mapping of the Research Front. Scientometrics, 65(2), 245-263.

Klang, D., Wallnöfer, M. \& Hacklin, F. (2014). The Business Model Paradox: A Systematic Review and Exploration of Antecedents. International Journal of Management Reviews, 16(4), 454-478.

Kovacs, A., Van Looy, B. \& Cassiman, B. (2015). Exploring the Scope of Open Innovation: A Bibliometric Review of a Decade of Research. Scientometrics, 104(3), 951-983.

Lakatos, I. (1969). Criticism and the Methodology of Scientific Research Programmes, Proceedings of the Aristotelian Society, New Series, 69 (1968-1969), 149-186.

Lakatos, I. (1970). History of Science and Its Rational Reconstructions, Proceedings of the Biennial Meeting of the Philosophy of Science Association, vol. 1970, 91-136.

Lecocq, X., Demil, B. \& Ventura, J. (2010). Business Models as a Research Program in Strategic Management: An Appraisal Based on Lakatos.M@n@gement, 13(4), 214-225.

Lee, C.I., Felps, W. \& Baruch, Y. (2014). Toward a Taxonomy of Career Studies through Bibliometric Visualization. Journal of Vocational Behavior, 85(3), 339-351.

Leydesdorff, L. \& Vaughan, L. (2006). Co-occurrence Matrices and their Applications in Information Science: Extending ACA to the Web Environment. Journal of the American Society for Information Science and Technology, 57(12), 1616-1628.

Lin, J. (1991). Divergence Measures based on the Shannon Entropy. Information Theory, IEEE Transactions on Information Theory, 37(1), 145-151.

Mangematin, V., Ravarini, A.M. \& Sharkey Scott, P. (2017). Practitioner Insights on Business Models and Future Directions. Journal of Business Strategy, 38(2), 3-5.

Massa, L., Tucci, C.L. \& Afuah, A. (2017). A Critical Assessment of Business Model Research. Academy of Management Annals, 11(1), 73-104.

McCain, K.W. (1990). Mapping Authors in Intellectual Space: A Technical Overview. Journal of the American Society for Information Science, 41(6), 433-443. 


\section{ARTICLE IN PRESS}

Moingeon, B. \& Lehmann-Ortega, L. (2010). Genèse et déploiement d'un nouveau business model : l'étude d'un cas désarmant.M@n@gement, 13(4),266-297.

Nerur, S.P., Rasheed, A.A. \& Natarajan, V. (2008). The Intellectual Structure of the Strategic Management Field: An Author Co-Citation Analysis. Strategic Management Journal, 29(3), 319336.

Noma, E. (1984). Co-Citation Analysis and the Invisible College. Journal of the American Society for Information Science, 35(1), 29-33.

Oorschot, J.A.W.H., Hofman, E., \& Halman, J.I.M. (2015). A Bibliometric Review of the Innovation Adoption Literature. Technological Forecasting and Social Change, 134, 1-21.

Osterwalder, A., Pigneur, Y. \& Tucci, C.L. (2005). Clarifying Business Models: Origins, Present, and Future of the Concept. Communications of the Association for Information Systems, 16(1), 125.

Porter, M.E. (2001). Strategy and the Internet. Harvard Business Review, 79, 62-78.

Prévot, F., Branchet, B., Boissin, J., Castagnos \& J., Guieu, G. (2010). The Intellectual Structure of the Competence-Based Management. Research in Competence-Based Management, 5, 231-258.

Pritchard, R.D. (1969). Equity Theory: A Review and Critique. Organizational Behavior and Human Performance, 4(2), 176-211.

Raghuram, S., Tuertscher, P. \& Garud, R. (2010). Research Note-Mapping the Field of Virtual Work: A Cocitation Analysis. Information Systems Research, 21(4), 983-999.

Renaud, A., Walsh, I. \& Kalika, M. (2016). Is SAM Still Alive? A Bibliometric and Interpretive Mapping of the Strategic Alignment Research Field. The Journal of Strategic Information Systems, 25(2), 75-103.

Salton, G. \& McGill, M. (1983), Introduction to Modern Information Retrieval, New York, NY: McGraw-Hill.

Samiee, S., Chabowski, B.R. \& Hult, G.T.M. (2015). International Relationship Marketing: Intellectual Foundations and Avenues for Further Research. Journal of International Marketing, 23(4), 1-21.

Schmidt, F.L. \& Hunter, J.E. (1977). Development of a General Solution to the Problem of Validity Generalization. Journal of Applied Psychology, 62(5), 529-540.

Schmidt, F. (2008). Meta-Analysis: A Constantly Evolving Research Integration Tool. Organizational Research Methods, 11(1), 96-113.

Schneider, S. \& Spieth, P. (2013). Business Model Innovation: Towards an Integrated Future Research Agenda. International Journal of Innovation Management, 17(1), 1-34.

Shafer, S.M., Smith, H.J. \& Linder, J.C. (2005). The Power of Business Models. Business Horizons, 48(3), 199-207.

Small, H. (1973). Co-Citation in the Scientific Literature: A New Measure of the Relationship between Two Documents. Journal of the American Society for Information Science, 24(4), 265269. 


\section{ARTICLE IN PRESS}

Spieth, P., Schneckenberg, D. \& Ricart, J.E. (2014). Business Model Innovation: State-of-the-Art and Future Challenges for the Field. R\&D Management, 44(3), 237-247.

Teece, D.J. (2010). Business Models, Business Strategy and Innovation. Long Range Planning, 43(2), 172-194.

Tranfield, D., Denyer, D. \& Smart, P. (2003). Towards a Methodology for Developing EvidenceInformed Management Knowledge by Means of Systematic Review. British Journal of Management, 14(3), 207-222.

Van Eck, N. \& Waltman, L. (2009). How to Normalize Co-occurrence Data? An Analysis of Some Well-known Similarity Measures. Journal of the American Society for Information Science and Technology, 60(8), 1635-1651.

Van Eck, N.J. \& Waltman, L. (2011), Text Mining and Visualization Using VosViewer, arXiv preprint arXiv:1109.2058.

Van Eck, N. \& Waltman, L., Dekker, R. \& Van den Berg, J. (2010). A Comparison of Two Techniques for Bibliometric Mapping: Multidimensional Scaling and VOS. Journal of the American Society for Information Science and Technology, 61(12), 2405-2416.

Vogel, R. \& Güttel, W.H. (2013). The Dynamic Capability View in Strategic Management: A Bibliometric Review. International Journal of Management Reviews, 15(4), 426-446.

Walsh, I. \& Renaud, A. (2017). Reviewing the Literature in the IS Field: Two Bibliometric Techniques to Guide Readings and Help the Interpretation of the Literature. Systèmes d'Information \& Management, 22(3), 75-115.

Waltman, L., Van Eck, N.J. \& Noyons, E.C. (2010). A Unified Approach to Mapping and Clustering of Bibliometric Networks. Journal of Informetrics, 4(4), 629-635.

Webster, J. \& Watson, R.T. (2002). Analyzing the Past to Prepare for the Future: Writing a Literature Review. MIS Quarterly, 26(2), 13-23.

White, H.D. \& Griffith, B.C. (1981). Author Cocitation: A Literature Measure of Intellectual Structure. Journal of the American Society for Information Science, 32(3), 163-171.

Wirtz, B.W., Pistoia, A., Ullrich, S. \& Göttel, V. (2016). Business Models: Origin, Development and Future Research Perspectives. Long Range Planning, 49(1), 36-54.

Zott, C., Amit, R. \& Massa, L. (2011). The Business Model: Recent Developments and Future Research. Journal of Management, 37(4), 1019-1042.

Zott, C. \& Amit, R. (2013). The Business Model: A Theoretically Anchored Robust Construct for Strategic Analysis. Strategic Organization, 11(4), 403-411.

Zupic, I. \& Čater, T. (2013). Bibliometric Methods in Management and Organization: A Review. Academy of Management Proceedings. Academy of Management, Chicago, 1, 13426p.

Zupic, I. \& Čater, T. (2015). Bibliometric Methods in Management and Organization. Organizational Research Methods, 18(3), 429-472. 


\section{ARTICLE IN PRESS}

\section{APPENDIX A. LITERATURE REVIEWS AND ESSAYS ON BM RESEARCH}

\begin{tabular}{|c|c|}
\hline Authors & $\begin{array}{c}\text { Type of contribution } \\
\text { Discipline } \\
\end{array}$ \\
\hline Al-Debei \& Avison (2010) & $\begin{array}{l}\text { Essay } \\
\text { Information Systems Management }\end{array}$ \\
\hline Baden-Fuller \& Mangematin (2013) & $\begin{array}{l}\text { Essay } \\
\text { Strategic Management }\end{array}$ \\
\hline Boons \& Ludeke-Freund (2013) & $\begin{array}{l}\text { Literature review } \\
\text { Business Ethics }\end{array}$ \\
\hline DaSilva \& Trkman (2014) & $\begin{array}{l}\text { Essay } \\
\text { Strategic Management }\end{array}$ \\
\hline Demil, et al. (2015) & $\begin{array}{l}\text { Essay } \\
\text { Innovation \& Entrepreneurship }\end{array}$ \\
\hline Foss \& Saebi (2017) & $\begin{array}{l}\text { Literature review } \\
\text { Generalist }\end{array}$ \\
\hline Hedman \& Kalling (2003) & $\begin{array}{l}\text { Essay } \\
\text { Information Systems Management }\end{array}$ \\
\hline Jensen (2013) & $\begin{array}{l}\text { Literature review } \\
\text { Strategic Management }\end{array}$ \\
\hline Klang, et al. (2014) & $\begin{array}{l}\text { Literature review } \\
\text { Generalist }\end{array}$ \\
\hline Lambert \& Davidson (2013) & $\begin{array}{l}\text { Literature review } \\
\text { Generalist }\end{array}$ \\
\hline Lecocq, et al. (2010) & $\begin{array}{l}\text { Essay } \\
\text { Generalist }\end{array}$ \\
\hline Massa, et al. (2017) & $\begin{array}{l}\text { Literature review } \\
\text { Generalist }\end{array}$ \\
\hline Osterwalder, et al. (2005) & $\begin{array}{l}\text { Literature review } \\
\text { Information Systems Management }\end{array}$ \\
\hline Schneider \& Spieth (2013) & $\begin{array}{l}\text { Literature review } \\
\text { Innovation \& Entrepreneurship }\end{array}$ \\
\hline Shafer, et al. (2005) & $\begin{array}{l}\text { Literature review } \\
\text { Generalist }\end{array}$ \\
\hline Spieth, et al. (2014) & $\begin{array}{l}\text { Literature review } \\
\text { Strategic Management }\end{array}$ \\
\hline Wirtz, et al. (2016) & $\begin{array}{l}\text { Literature review } \\
\text { Strategic Management }\end{array}$ \\
\hline Zott \& Amit (2013) & $\begin{array}{l}\text { Essay } \\
\text { Strategic Management }\end{array}$ \\
\hline Zott, et al. (2011) & $\begin{array}{l}\text { Literature review } \\
\text { Generalist }\end{array}$ \\
\hline
\end{tabular}

The data collection was carried out between 2005 and 2017 through a keyword-based search in titles, keywords and abstracts in the Scopus, EBSCOhost, and Google Scholar databases. 


\section{ARTICLE IN PRESS}

\section{APPENDIX B: INTELLECTUAL PILLARS OF BUSINESS MODEL RESEARCH}

\section{Cluster 1. Theoretical grounding of the concept}

\section{Strategic Management (Cluster 1SM)}

Barney, J.B. (1991). Firm Resources and Sustained Competitive Advantage, Journal of Management, 17(1), 99-120.

Christensen, C.M. (1997), The Innovator's Dilemma: When New Technologies Cause Great Firms to Fail, Boston, Ma: Harvard Business School Press.

Eisenhardt, K.M. (1989). Building Theories from Case Study Research. Academy of Management Review, 14(4), 532-550.

Johanson, J. \& Vahlne, J.E. (1977). The Internationalization Process of The Firm. A Model of Knowledge Development and Increasing Foreign Market Commitments. Journal of International Business Studies, 8(1), 23-32.

Nelson, R.R. \& Winter, S.G. (1982), An Evolutionary Theory of Economic Change, Cambridge, Mass: Belknap Press, Harvard University Press.

Porter, M.E. (1980), Competitive Strategy: Techniques for Analyzing Industries and Competitors, New York, NY: The Free Press.

Porter, M.E. (1985), Competitive Advantage: Creating and Sustaining Superior Performance, New York, NY: The Free Press.

Porter, M.E. (1996). What is Strategy? Harvard Business Review, 74(6), 61-78.

Prahalad, C.K. (2004), The Fortune at The Bottom of The Pyramid: Eradicating Poverty Through Profits, Upper Saddle River: Wharton School Publishing.

Schumpeter, J.A. (1934), Change and the Entrepreneur, Essays of JA Schumpeter.

Teece, D.J. (1986). Profiting from Technological Innovation: Implications for Integration, Collaboration, Licensing and Public Policy. Research Policy, 15(6), 285-305.

Teece, D.J., Pisano, G. \& Shuen, A. (1997). Dynamic Capabilities and Strategic Management. Strategic Management Journal, 18(7), 509-533.

Wernerfelt, B. (1984). A Resource-Based View of The Firm. Strategic Management Journal, 5(2), 171-180.

Yin, R.K. (1989), Case Study Research: Design and Methods, London: Sage.

\section{Innovation \& Entrepreneurship (Cluster 1IE)}

Barney, J.B. (1991). Firm Resources and Sustained Competitive Advantage, Journal of Management, 17(1), 99-120.

Chesbrough, H.W. (2003), Open Innovation: The New Imperative for Creating and Profiting from Technology, Harvard Business Press.

Christensen, C.M. (1997), The Innovator's Dilemma: When New Technologies Cause Great Firms to Fail, Boston, Ma: Harvard Business School Press. 


\section{ARTICLE IN PRESS}

Cohen, W.M. \& Levinthal, D.A. (1990). Absorptive Capacity: A New Perspective on Learning and Innovation, Administrative Science Quarterly, 35(1), 128-152.

Hamel, G. (2002), Leading the Revolution: How to Thrive in Turbulent Times by Making Innovation a Way of Life, Boston, Ma: Harvard Business School Press.

March, J.G. (1991). Exploration and Exploitation in Organizational Learning. Organization Science, 2(1), 71-87.

Penrose, E. (1959), The Theory of The Growth of The Firm, London: Basil Blackwell.

Porter, M.E. (1980), Competitive Strategy: Techniques for Analyzing Industries and Competitors, New York, NY: The Free Press.

Porter, M.E. (1985), Competitive Advantage: Creating and Sustaining Superior Performance, New York, NY: The Free Press.

Teece, D.J. (1986). Profiting from Technological Innovation: Implications for Integration, Collaboration, Licensing and Public Policy. Research Policy, 15(6), 285-305.

Teece, D.J., Pisano, G. \& Shuen, A. (1997). Dynamic Capabilities and Strategic Management. Strategic Management Journal, 18(7), 509-533.

\section{Cluster 2. Theoretical and practical legitimization of the concept}

\section{Strategic Management (Cluster 2SM)}

Amit, R. \& Zott, C. (2001). Value Creation In e-Business, Strategic Management Journal, 22(67), 493-520.

Chesbrough, H.W. (2003), Open Innovation: The New Imperative for Creating and Profiting from Technology, Harvard Business Press.

Chesbrough, H.W. \& Rosenbloom, R.S. (2002). The Role of the Business Model in Capturing Value from Innovation: Evidence from Xerox Corporation's Technology Spinoff Companies. Industrial and Corporate Change, 11, 533-534.

Johnson, M.W., Christensen, C.M. \& Kagermann, H. (2008). Reinventing Your Business Model. Harvard Business Review, 86(12), 50-59.

Magretta, J. (2002). Why Business Models Matter. Harvard Business Review, 80(5), 86-92.

Morris, M., Schindehutte, M. \& Allen, J. (2005). The Entrepreneur's Business Model: Toward a Unified Perspective, Journal of Business Research, 58(6), 726-735.

Osterwalder, A., Pigneur, Y. \& Tucci, C.L. (2005). Clarifying Business Models: Origins, Present, And Future of the Concept. Communications of The Association for Information Systems (AIS), 15, 751-775.

Shafer, S.M., Smith, H.J. \& Linder, J.C. (2005). The Power of Business Models. Business Horizons, 48(3), 199-207.

Zott, C. \& Amit, R. (2007). Business Model Design and The Performance of Entrepreneurial Firms. Organization Science, 18(2), 181-202. 


\section{ARTICLE IN PRESS}

Zott, C. \& Amit, R. (2008). The Fit Between Product Market Strategy and Business Model: Implications for Firm Performance. Strategic Management Journal, 29(1), 1-26.

\section{Innovation \& Entrepreneurship (Cluster 2IE)}

Amit, R. \& Zott, C. (2001). Value Creation In e-Business, Strategic Management Journal, 22(67), 493-520.

Chesbrough, H.W. (2006). Open Business Model: How to Thrive in The New Innovation Landscape. Boston, Ma: Harvard Business School Press.

Chesbrough, H.W. \& Rosenbloom, R.S. (2002). The Role of the Business Model in Capturing Value from Innovation: Evidence from Xerox Corporation's Technology Spinoff Companies. Industrial and Corporate Change, 11, 533-534.

Morris, M., Schindehutte, M. \& Allen, J. (2005). The Entrepreneur's Business Model: Toward a Unified Perspective, Journal of Business Research, 58(6), 726-735.

Osterwalder, A. \& Pigneur, Y. (2010), Business Model Generation: A Handbook for Visionaries, Game Changers, and Challengers, John Wiley and Sons.

Osterwalder, A., Pigneur, Y. \& Tucci, C.L. (2005). Clarifying Business Models: Origins, Present, And Future of the Concept. Communications of The Association for Information Systems (AIS), 15, 751-775.

Shafer, S.M., Smith, H.J. \& Linder, J.C. (2005). The Power of Business Models. Business Horizons, 48(3), 199-207.

\section{Cluster 3. Empowerment of the concept}

\section{Strategic Management (Cluster 3SM)}

Baden-Fuller, C. \& Haefliger, S. (2013). Business Models and Technological Innovation. Long Range Planning, 46(6), 419-426.

Baden-Fuller, C. \& Mangematin, V. (2013). Business Models: A Challenging Agenda. Strategic Organization, 11(4), 418-427.

Baden-Fuller, C. \& Morgan, M.S. (2010). Business Models as Models. Long Range Planning, 43(2-3), 156-171.

Casadesus-Masanell, R. \& Ricart, J.E. (2010). From Strategy to Business Models and Onto Tactics. Long Range Planning, 43(23), 195-215.

Demil, B. \& Lecocq, X. (2010). Business Model Evolution: In Search of Dynamic Consistency. Long Range Planning, 43(2-3), 227-246.

Doz, Y.L. \& Kosonen, M. (2010). Embedding Strategic Agility: A Leadership Agenda for Accelerating Business Model Renewal. Long Range Planning, 43(2), 370-382.

McGrath, R.G., (2010). Business Models: A Discovery Driven Approach. Long Range Planning, 43(2-3), 347-361.

Osterwalder, A. \& Pigneur, Y. (2010), Business Model Generation: A Handbook for Visionaries, Game Changers, and Challengers, John Wiley and Sons. 


\section{ARTICLE IN PRESS}

Sosna, M., Trevinyo-Rodriguez, R.N. \& Velamuri, S.R. (2010). Business Model Innovation Through Trial-And-Error Learning: The Naturhouse Case. Long Range Planning, 43(2-3), 383407.

Teece, D.J. (2010). Business Models, Business Strategy and Innovation. Long Range Planning, 43(2-3), 172-194.

Zott, C. \& Amit, R. (2010). Business Model Design: An Activity System Perspective. Long Range Planning, 43(2-3), 216-226.

Zott, C., Amit, R. \& Massa, L. (2011). The Business Model: Recent Developments and Future Research. Journal of Management, 37(4), 1019-1042.

\section{Innovation \& Entrepreneurship (Cluster 3IE)}

Baden-Fuller, C. \& Morgan, M.S. (2010). Business Models as Models. Long Range Planning, 43(2-3), 156-171.

Casadesus-Masanell, R. \& Ricart, J.E. (2010). From Strategy to Business Models and Onto Tactics. Long Range Planning, 43(23), 195-215.

Chesbrough, H. (2010). Business Model Innovation: Opportunities and Barriers. Long Range Planning, 43(2-3), 354-363.

Demil, B. \& Lecocq, X. (2010). Business Model Evolution: In Search of Dynamic Consistency. Long Range Planning, 43(2-3), 227-246.

George, G. \& Bock, A.J. (2011). The Business Model in Practice and its Implications for Entrepreneurship Research. Entrepreneurship: Theory and Practice, 35(1), 83-111.

Johnson, M.W., Christensen, C.M. \& Kagermann, H. (2008). Reinventing Your Business Model. Harvard Business Review, 86(12), 50-59.

Markides, C. (2006). Disruptive Innovation: In Need of Better Theory. The Journal of Product Innovation Management, 23(1), 19-25.

McGrath, R.G. (2010). Business Models: A Discovery Driven Approach. Long Range Planning, 43(2-3), 347-361.

Sosna, M., Trevinyo-Rodriguez, R.N. \& Velamuri, S.R. (2010). Business Model Innovation Through Trial-And-Error Learning: The Naturhouse Case. Long Range Planning, 43(2-3), 383407.

Teece, D.J. (2010). Business Models, Business Strategy and Innovation. Long Range Planning, 43(2-3), 172-194.

Zott, C. \& Amit, R. (2007). Business Model Design and The Performance of Entrepreneurial Firms. Organization Science, 18(2), 181-202.

Zott, C. \& Amit, R. (2008). The Fit Between Product Market Strategy and Business Model: Implications for Firm Performance. Strategic Management Journal, 29(1), 1-26.

Zott, C. \& Amit, R. (2010). Business Model Design: An Activity System Perspective. Long Range Planning, 43(2-3), 216-226. 


\section{ARTICLE IN PRESS}

Zott, C., Amit, R. \& Massa, L. (2011). The Business Model: Recent Developments and Future

Research. Journal of Management, 37(4), 1019-1042.

\section{Cluster 4. Methodological sources}

\section{Innovation \& Entrepreneurship (Cluster 4IE)}

Eisenhardt, K.M. (1989). Building Theories from Case Study Research. Academy of Management Review, 14(4), 532-550.

Eisenhardt, K.M. \& Graebner, M.E. (2007). Theory Building from Cases: Opportunities and Challenges. Academy of Management Journal, 50(1), 25-32.

Miles, M.B. \& Huberman, A.M. (1994), Qualitative Data Analyses: An Expanded Sourcebook, Thousand Oaks, CA: Sage Publications.

Yin, R.K. (1989), Case Study Research: Design and Methods, London: Sage. 


\section{ARTICLE IN PRESS}

\section{APPENDIX C: RESEARCH AREAS IN BUSINESS MODEL RESEARCH}

\section{Strategic Management literature}

\section{Cluster 1. Essentialist perspective}

Achtenhagen, L., Melin, L. \& Naldi, L. (2013). Dynamics of Business Models-Strategizing, Critical Capabilities and Activities for Sustained Value Creation. Long Range Planning, 46(6), 427-442.

Amit, R. \& Zott, C. (2001). Value Creation in E-Business. Strategic Management Journal, 22(67), 493-520.

Arend, R.J. (2013). The Business Model: Present and Future Beyond a Skeumorph. Strategic Organization, 11(4), 390-402.

Berghman, L., Matthyssens, P., Streukens, S. \& Vandenbempt, K. (2013). Deliberate Learning Mechanisms for Stimulating Strategic Innovation Capacity. Long Range Planning, 46(1-2), 39-71.

Breunig, K.J., Kvålshaugen, R. \& Hydle, K.M. (2014). Knowing Your Boundaries: Integration Opportunities in International Professional Service Firms. Journal of World Business, 49(4), 502511.

Casadesus-Masanell, R. \& Ricart, J.E. (2010). From Strategy to Business Models and Onto Tactics. Long Range Planning, 43(2-3), 195-215.

Casadesus-Masanell, R. \& Zhu, F. (2013). Business Model Innovation and Competitive Imitation: The Case of Sponsor-Based Business Models. Strategic Management Journal, 34(4), 464-482.

Casprini, E., Pucci, T. \& Zanni, L. (2014). Business Model Shifts: A Case Study on Firms That Apply High Technology to Cultural Goods. Technology Analysis \& Strategic Management, 26(2), 171-187.

Demil, B. \& Lecocq, X. (2010). Business Model Evolution: In Search of Dynamic Consistency. Long Range Planning, 43(2-3), 227-246.

Maitland, E. \& Sammartino, A. (2015). Managerial Cognition and Internationalization. Journal of International Business Studies, 46(7), 733-760.

McQuillan, D. \& Sharkey Scott, P. (2015). Models of Internationalization: A Business Model Approach to Professional Service Firm Internationalization. In C. Baden-Fuller \& V. Mangematin (eds.), Business Models and Modelling (pp. 309-345). Emerald Group Publishing Limited.

Ricart, J.E., Enright, M.J., Ghemawat, P., Hart, S.L. \& Khanna, T. (2004). New Frontiers in International Strategy. Journal of International Business Studies, 35(3), 175-200.

Sinkovics, N., Sinkovics, R.R. \& Yamin, M. (2014). The Role of Social Value Creation in Business Model Formulation at The Bottom of the Pyramid-Implications for MNEs? International Business Review, 23(4), 692-707.

Sosna, M., Trevinyo-Rodríguez, R.N. \& Velamuri, S.R. (2010). Business Model Innovation Through Trial-And-Error Learning: The Naturhouse Case. Long Range Planning, 43(2-3), 383407. 


\section{ARTICLE IN PRESS}

Svejenova, S., Planellas, M. \& Vives, L. (2010). An Individual Business Model in The Making: A Chef's Quest for Creative Freedom. Long Range Planning, 43(2-3), 408-430.

Verstraete, T. \& Jouison-Laffitte, E. (2011). A Conventionalist Theory of the Business Model in the Context of Business Creation for Understanding Organizational Impetus. Management International, 15(2), 109-124.

Yunus, M., Moingeon, B. \& Lehmann-Ortega, L. (2010). Building Social Business Models: Lessons from the Grameen Experience. Long Range Planning, 43(2-3), 308-325.

\section{Cluster 2. Cognitive perspective}

Aspara, J., Lamberg, J.A., Laukia, A. \& Tikkanen, H. (2013). Corporate Business Model Transformation and Inter-Organizational Cognition: The Case of Nokia. Long Range Planning, 46(6), 459-474.

Aversa, P., Haefliger, S., Rossi, A. \& Baden-Fuller, C. (2015). From Business Model to Business Modelling: Modularity and Manipulation. In C. Baden-Fuller \& V. Mangematin (eds.), Business Models and Modelling (pp. 151-185). Emerald Group Publishing Limited.

Baden-Fuller, C. \& Haefliger, S. (2013). Business Models and Technological Innovation. Long Range Planning, 46(6), 419-426.

Baden-Fuller, C. \& Mangematin, V. (2013). Business Models: A Challenging Agenda. Strategic Organization, 11(4), 418-427.

Baden-Fuller, C. \& Morgan, M.S. (2010). Business Models as Models. Long Range Planning, 43(2-3), 156-171.

Furnari, S. (2015). A Cognitive Mapping Approach to Business Models: Representing Causal Structures and Mechanisms. In C. Baden-Fuller \& V. Mangematin (eds.), Business Models and Modelling (pp. 207-239). Emerald Group Publishing Limited.

Hienerth, C., Keinz, P. \& Lettl, C. (2011). Exploring the Nature and Implementation Process of User-Centric Business Models. Long Range Planning, 44(5-6), 344-374.

Kodama, M. (2009). Boundaries Innovation and Knowledge Integration in the Japanese Firm. Long Range Planning, 42(4), 463-494.

Rumble, R. \& Mangematin, V. (2015). Business Model Implementation: The Antecedents of Multi-Sidedness. In C. Baden-Fuller \& V. Mangematin (eds.), Business Models and Modelling (pp. 97-131). Emerald Group Publishing Limited.

Van den Oever, K. \& Martin, X. (2015). Business Model Change: Managerial Roles and Tactics in Decision-Making. In C. Baden-Fuller \& V. Mangematin (eds.), Business Models and Modelling (pp. 387-420). Emerald Group Publishing Limited.

Waldner, F., Poetz, M.K., Grimpe, C. \& Eurich, M. (2015). Antecedents and Consequences of Business Model Innovation: The Role of Industry Structure. In C. Baden-Fuller \& V. Mangematin (eds.), Business Models and Modelling (pp. 347-386). Emerald Group Publishing Limited.

Zhang, J., Lichtenstein, Y. \& Gander, J. (2015). Designing Scalable Digital Business Models. In

C. Baden-Fuller \& V. Mangematin (eds.), Business Models and Modelling (pp. 241-277). Emerald Group Publishing Limited. 


\section{ARTICLE IN PRESS}

\section{Innovation \& Entrepreneurship literature}

\section{Cluster 1. Business model innovation}

Cardeal, N.C., Abecassis-Moedas, C. \& Antonio, N.S. (2014). Shared Cluster Resources as A Source of Core Capabilities. International Journal of Entrepreneurship and Small Business, 21(1), $55-78$.

Enkel, E. \& Mezger, F., (2013). Imitation Processes and Their Application for Business Model Innovation: An Explorative Study. International Journal of Innovation Management, 17(1), 1-34.

Gerasymenko, V., De Clercq, D. \& Sapienza, H.J. (2015). Changing the Business Model: Effects of Venture Capital Firms and Outside CEOs on Portfolio Company Performance. Strategic Entrepreneurship Journal, 9(1), 79-98.

Ghezzi, A., Cavallaro, A., Rangone, A. \& Balocco, R. (2015). On Business Models, Resources and Exogenous (Dis)continuous Innovation: Evidences from The Mobile Applications Industry. International Journal of Technology Management, 68(42401), 21-48.

Landau, C., Karna, A. \& Sailer, M. (2016). Business Model Adaptation for Emerging Markets: A Case Study of a German Automobile Manufacturer in India. R\&D Management, 46(3), 480-503.

Mezger, F. \& Toward, A. (2014). Capability-Based Conceptualization of Business Model Innovation: Insights from an Explorative Study. R\&D Management, 44(5), 429-449.

Obloj, T., Obloj, K. \& Pratt, M.G. (2010). Dominant Logic and Entrepreneurial Firms' Performance in a Transition Economy. Entrepreneurship: Theory and Practice, 34(1), 151-170.

Osiyevskyy, O. \& Dewald, J. (2015). Explorative Versus Exploitative Business Model Change: The Cognitive Antecedents of Firm-Level Responses to Disruptive Innovation. Strategic Entrepreneurship Journal, 9(1), 58-78.

Schneider, S. \& Spieth, P. (2014). Business Model Innovation and Strategic Flexibility: Insights from An Experimental Research Design. International Journal of Innovation Management, 18(6), $1-21$.

\section{Cluster 2. Business model capabilities}

Andries, P. \& Debackere, K. (2013). Business Model Innovation: Propositions on The Appropriateness of Different Learning Approaches. Creativity and Innovation Management, 22(4), 337-358.

Bicen, P. \& Johnson, W.H.A. (2015) Radical Innovation with Limited Resources in HighTurbulent Markets: The Role of Lean Innovation Capability. Creativity and Innovation Management, 24(2), 278-299.

Carayannis, E.G., Sindakis, S. \& Walter, C. (2015) Business Model Innovation as Lever of Organizational Sustainability. Journal of Technology Transfer, 40(1), 85-104.

Cucculelli, M. \& Bettinelli, C. (2015). Business Models, Intangibles and Firm Performance: Evidence on Corporate Entrepreneurship from Italian Manufacturing SMEs. Small Business Economics, 45(2), 329-350.

Doganova, L. \& Eyquem-Renault, M. (2009). What Do Business Models Do? Innovation Devices in Technology Entrepreneurship. Research Policy, 38(10), 1559-1570. 


\section{ARTICLE IN PRESS}

Miller, K., Mcadam, M. \& Mcadam, R. (2014). The Changing University Business Model: A Stakeholder Perspective. R\&D Management, 44(3), 265-287.

Mustar, P., Renault, M., Colombo, M.G., Piva, E., Fontes, M., Lockett, A., Wright, M., Clarysse, B. \& Moray, N. (2006). Conceptualising The Heterogeneity of Research-Based Spin-Offs: A Multi-Dimensional Taxonomy. Research Policy, 35(2), 289-308.

Schindehutte, M., Morris, M.H. \& Kocak, A. (2008). Understanding Market-Driving Behavior: The Role of Entrepreneurship. Journal of Small Business Management, 46(1), 4-26.

Tasavori, M., Zaefarian, R. \& Ghauri, P.N. (2015). The Creation View of Opportunities at The Base of The Pyramid. Entrepreneurship and Regional Development, 27, 106-126.

Trimi, S. \& Berbegal-Mirabent, J. (2012). Business Model Innovation in Entrepreneurship. International Entrepreneurship and Management Journal, 8(4), 449-465.

Winterhalter, S., Zeschky, M.B. \& Gassmann, O. (2016). Managing Dual Business Models in Emerging Markets: An Ambidexterity Perspective. R\&D Management, 46(3), 464-479.

\section{Cluster 3. Open innovation}

Anokhin, S., Wincent, J. \& Frishammar, J. (2011). A Conceptual Framework for Misfit Technology Commercialization. Technological Forecasting and Social Change, 78(6), 1060-1071.

Bogers, M., Hadar, R. \& Bilberg, A. (2016). Additive Manufacturing for Consumer-Centric Business Models: Implications for Supply Chains in Consumer Goods Manufacturing. Technological Forecasting and Social Change, 102, 225-239.

Braun, A. (2015). Linking Business Model and Open Innovation - Success and Failure of Collaborations. International Journal of Entrepreneurship and Innovation Management, 19(42401), 59-76.

Brolo, A. (2009). Innovative Coopetition: The Strength of Strong Ties. International Journal of Entrepreneurship and Small Business, 8(1), 110-134.

Denicolai, S., Ramirez, M. \& Tidd, J. (2014). Creating and Capturing Value from External Knowledge: The Moderating Role of Knowledge Intensity. R\&D Management, 44(3), 248-264.

Frankenberger, K., Weiblen, T. \& Gassmann, O. (2014). The Antecedents of Open Business Models: An Exploratory Study of Incumbent Firms. R\&D Management, 44(2), 173-188.

Gunzel, F. \& Holm, A.B. (2013). One Size Does Not Fit All. Understanding the Front-End and Back-End of Business Model Innovation. International Journal of Innovation Management, 17(1), $1-34$.

Herzog, P. \& Leker, J. (2010). Open and Closed Innovation - Different Innovation Cultures for Different Strategies. International Journal of Technology Management, 52(42463), 322-343.

Holm, A.B., Gunzel, F. \& Ulhoi, J.P. (2013). Openness in Innovation and Business Models: Lessons from The Newspaper Industry. International Journal of Technology Management, 61(42463), 324-348.

Kodama, M. (2007). Innovation and Knowledge Creation Through Leadership-Based Strategic Community: Case Study on High-Tech Company in Japan. Technovation, 27(3), 115-132. 


\section{ARTICLE IN PRESS}

Krech, C.A., Ruther, F. \& Gassmann, O. (2015). Profiting from Invention: Business Models of Patent Aggregating Companies. International Journal of Innovation Management, 19(3), 1-26.

Mina, A., Bascavusoglu-Moreau, E. \& Hughes, A. (2014). Open Service Innovation and The Firm's Search for External Knowledge. Research Policy, 43(5), 853-866.

Scaringella, L. (2014). Smart-Stolen Tacit Knowledge: Institutional Arrangements for Invited Piracy. International Journal of Entrepreneurship and Small Business, 22(4), 495-518.

\section{Cluster 4. Disruption and industry dynamics}

Bergek, A., Berggren, C., Magnusson, T. \& Hobday, M. (2013). Technological Discontinuities and The Challenge for Incumbent Firms: Destruction, Disruption or Creative Accumulation? Research Policy, 42(42557), 1210-1224.

Habtay, S.R. (2012). A Firm-Level Analysis on The Relative Difference Between TechnologyDriven and Market-Driven Disruptive Business Model Innovations. Creativity and Innovation Management, 21(3), 290-303.

Habtay, S.R. \& Holmen, M. (2014). Incumbents Responses to Disruptive Business Model Innovation: The Moderating Role of Technology vs. Market-Driven Innovation. International Journal of Entrepreneurship and Innovation Management, 18(4), 289-309.

Khanagha, S., Volberda, H. \& Oshri, I., (2014). Business Model Renewal and Ambidexterity: Structural Alteration and Strategy Formation Process During Transition to A Cloud Business Model. R\&D Management, 44(3), 322-340.

Kim, S.K. \& Min, S. (2015). Business Model Innovation Performance: When Does Adding a New Business Model Benefit an Incumbent? Strategic Entrepreneurship Journal, 9(1), 34-57.

Sabatier, V., Craig-Kennard, A. \& Mangematin, V. (2012). When Technological Discontinuities and Disruptive Business Models Challenge Dominant Industry Logics: Insights from The Drugs Industry. Technological Forecasting and Social Change, 79(5), 949-962.

Velu, C. (2015). Business Model Innovation and Third-Party Alliance on The Survival of New Firms. Technovation, 35, 1-11.

Wan, F., Williamson, P.J. \& Yin, E. (2015). Antecedents and Implications of Disruptive Innovation: Evidence from China. Technovation, 39-40(1), 94-104.

\section{Cluster 5. Customer-oriented business models}

Abdelkafi, N., Makhotin, S. \& Posselt, T. (2013). Business Model Innovations for Electric Mobility-What Can Be Learned from Existing Business Model Patterns? International Journal of Innovation Management, 17(1), 1-41.

Cheng, C.C.J., Shiu, E.C.C. \& Dawson, J.A. (2014). Service Business Model and Service Innovativeness. International Journal of Innovation Management, 18(2), 1-22.

Clauss, T., Laudien, S.M. \& Daxbock, B. (2014). Service-Dominant Logic and The Business Model Concept: Toward A Conceptual Integration. International Journal of Entrepreneurship and Innovation Management, 18(4), 266-288. 


\section{ARTICLE IN PRESS}

Dmitriev, V., Simmons, G., Truong, Y., Palmer, M. \& Schneckenberg, D. (2014). An Exploration of Business Model Development in The Commercialization of Technology Innovations. $R \& D$ Management, 44(3), 306-321.

Rohrbeck, R., Konnertz, L. \& Knab, S. (2013). Collaborative Business Modelling for Systemic and Sustainability Innovations. International Journal of Technology Management, 63(42401), 4-23.

Spickermann, A., Grienitz, V. \& Von Der Gracht, H.A. (2014). Heading Towards a Multimodal City of The Future: Multi-Stakeholder Scenarios for Urban Mobility. Technological Forecasting and Social Change, 89, 201-221.

Tongur, S. \& Engwall, M. (2014). The Business Model Dilemma of Technology Shifts. Technovation, 34(9), 525-535.

Wei, Z., Yang, D., Sun, B. \& Gu, M. (2014). The Fit Between Technological Innovation and Business Model Design for Firm Growth: Evidence from China. R\&D Management, 44(3), 288305. 


\section{ARTICLE IN PRESS}

\section{APPENDIX D: CCA MAPPING OF THE LITERATURE ON STRATEGIC MANAGEMENT}

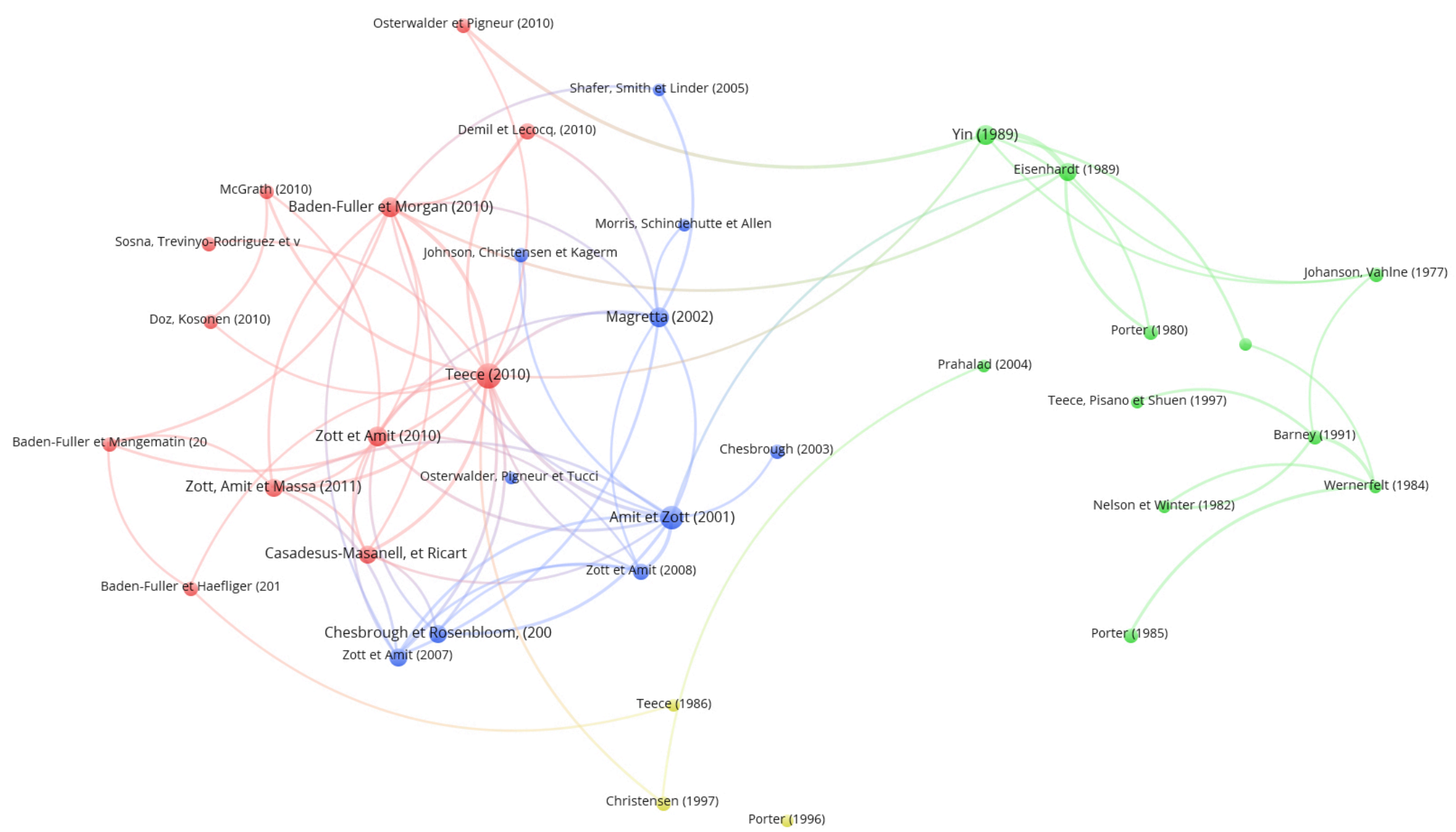




\section{ARTICLE IN PRESS}

\section{APPENDIX E: CCA MAPPING OF THE LITERATURE ON INNOVATION \& ENTREPRENEURSHIP}

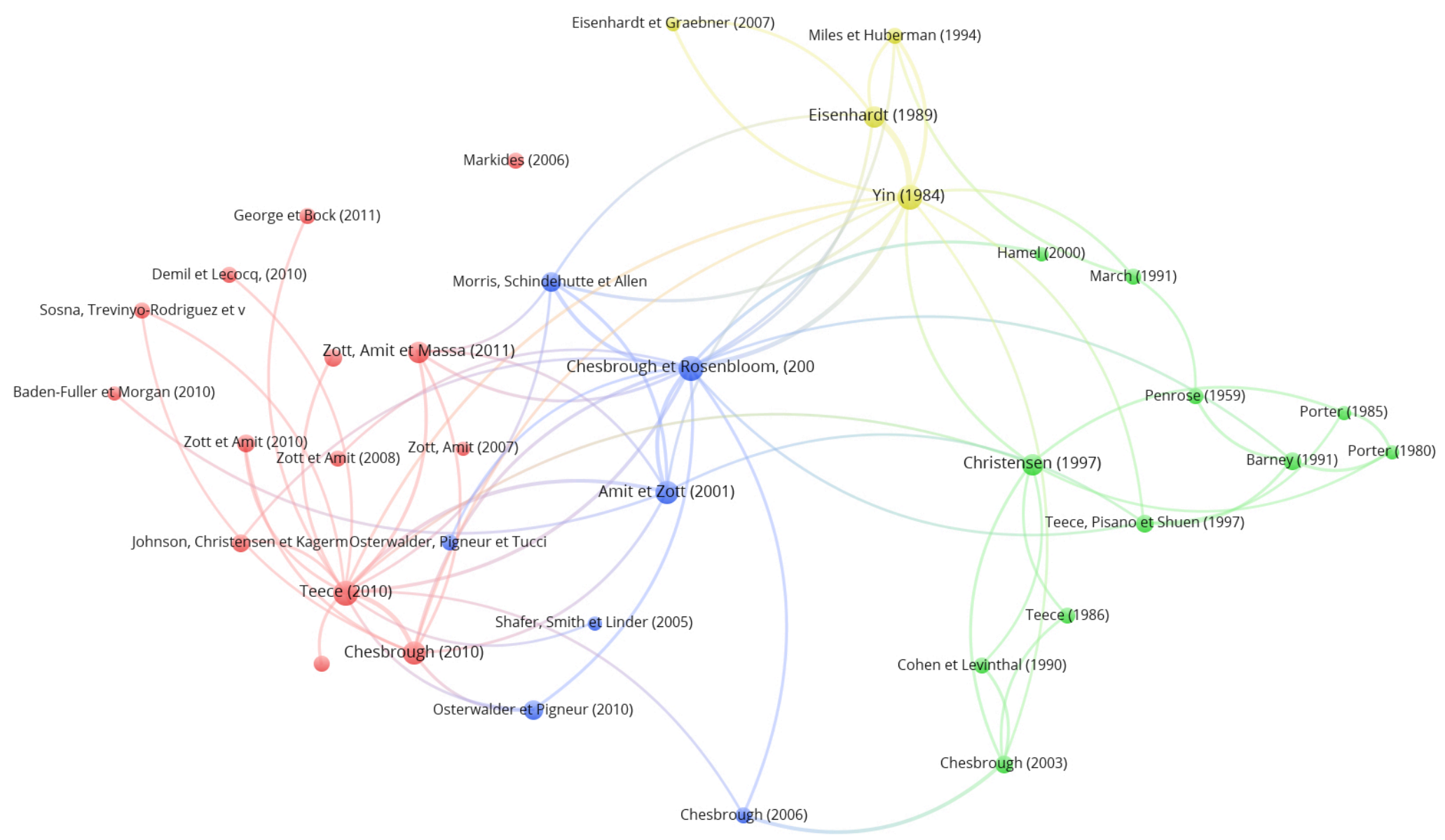




\section{ARTICLE IN PRESS}

Raphaël Maucuer is an Associate Professor of Strategy at ESSCA School of Management. He holds a $\mathrm{PhD}$ in Management Sciences from the University of Paris-Dauphine. His research interests include business models, strategic discourses and non-profit organizations.

Alexandre Renaud is an Associate Professor of Strategy at EM Normandie. He holds a PhD in Management Sciences from the University of Paris-Dauphine. His research interests include strategic alignment, project management and information systems reconfiguration. 